\title{
SPACE IS THE DESTINY: RESEARCH OF THE SOLAR SYSTEM. ON THE OCCASION OF THE 85-TH ANNIVERSARY OF ACADEMICIAN RAS M. Ya. MAROV
}

\section{B.N. CHETVERUSHKIN ${ }^{1}$, A.I. APTEKAREV ${ }^{2}$, A.V.KOLESNICHENKO ${ }^{3 *}$, V.I. MAZHUKIN ${ }^{4}$, V.P. OSIPOV}

\author{
${ }^{1}$ Scientific chief of Keldysh Institute of Applied Mathematics of RAS, Academician of RAS, \\ Professor, Moscow, Russia \\ ${ }^{2}$ Director of Keldysh Institute of Applied Mathematics of RAS, Corresponding member of RAS, \\ Professor, Moscow, Russia \\ ${ }^{3}$ Principal researcher of Keldysh Institute of Applied Mathematics of RAS \\ Professor, Moscow, Russia \\ ${ }^{4}$ Principal researcher of Keldysh Institute of Applied Mathematics of RAS, \\ Professor, Moscow, Russia \\ ${ }^{5}$ Leading researcher of Keldysh Institute of Applied Mathematics of RAS, \\ Moscow, Russia \\ *Corresponding author. E-mail: kolesn@keldysh.ru
}

DOI: $10.20948 /$ mathmontis-2019-46-15

Summary. The paper is dedicated to the 85-th anniversary of the outstanding Russian scientist, full member (Academician) of the Russian Academy of Sciences Mikhail Yakovlevich Marov. Academician M.Ya. Marov is a Soviet and Russian physicist and astronomer, a leading Russian scientist in the field of theoretical and experimental study of the solar system, comparative planetology, and mathematical modeling natural and cosmic media. He owns the outstanding pioneering results of Venus and Mars research, which received widespread worldwide recognition. For the first time in the world, he carried out direct in situ measurements of temperature and pressure on the surfaces of Venus and Mars, conducted thorough studies of the thermal regime of Venus, peculiar dynamics of its atmosphere, and the structure and properties of clouds. He played a leading role in solving the complex problem of landing and operation of Soviet vehicles on the hot surface of Venus, which allowed us to transmit to Earth first dark and white and then color panoramas of the neighbor planet and to measure elemental composition of its rocks. He has been deeply involved is in the development and implementation of the planetary space programs «The Moon», «Venus», «Vega», «Mars», «Phobos».

The area of scientific interests of M.Ya. Marov is very broad. He is basic in mechanics and physics of space, astrophysics, planetology, mathematical modeling of space media. He made a great contribution to the advancement of our knowledge on space environment. They include the fundamentals of planetary aeronomy, mechanics of multicomponent turbulent reacting gases and heterogeneous multiphase media, non-equilibrium kinetic processes, original methods of mathematical modeling the atmospheres of planets and gas envelops of comets, migration-collisional processes of small bodies in the outer space. Thought his scientific career he nicely combined theoretical and experimental studies and took leading part in managing a few the world recognized space projects.

This biographical sketch reflects the view of many colleagues of Mikhail Yakovlevich at the Keldysh Institute of Applied Mathematics of RAS, in which he worked for about half a century - it is objective and equitable while not impartial, but imbued with admiration, respect and love.

2010 Mathematics Subject Classification: $85 \mathrm{~A} 35,91 \mathrm{~B} 50,82 \mathrm{C} 40$.

Key words and Phrases: Continuum mechanics, non-equilibrium kinetic processes, planetary research and cosmogony. 


\section{THE BEGINNING OF THE CREATIVE CAREER}

As fate would have it, Mikhail Yakovlevich (Fig. 1.) found himself on a stretch of space and time when humanity opened an opportunity to go into outer space, began to study and master it. He had a chance to take a direct part in this truly historic achievement in a great country - the former Soviet Union - from almost the very first steps. He was lucky enough to pursue his favorite science for many years, along with numerous colleagues and students in two excellent organizations of the Russian Academy of Sciences, where he has been working: at the Keldysh Institute of Applied Mathematics (IAM RAS) as a Head of the Department of Applied Mechanics, Space Research and Aeronomy, and currently, at the Vernadsky Institute of Geochemistry and Analytical Chemistry (GEOCHI RAS) where he occupies the position of a Head of the Department of Planetary Sciences and Cosmochemistry. He maintains a close cooperation between IAM, GEOCHI and Space Research Institute (IKI) in space projects.

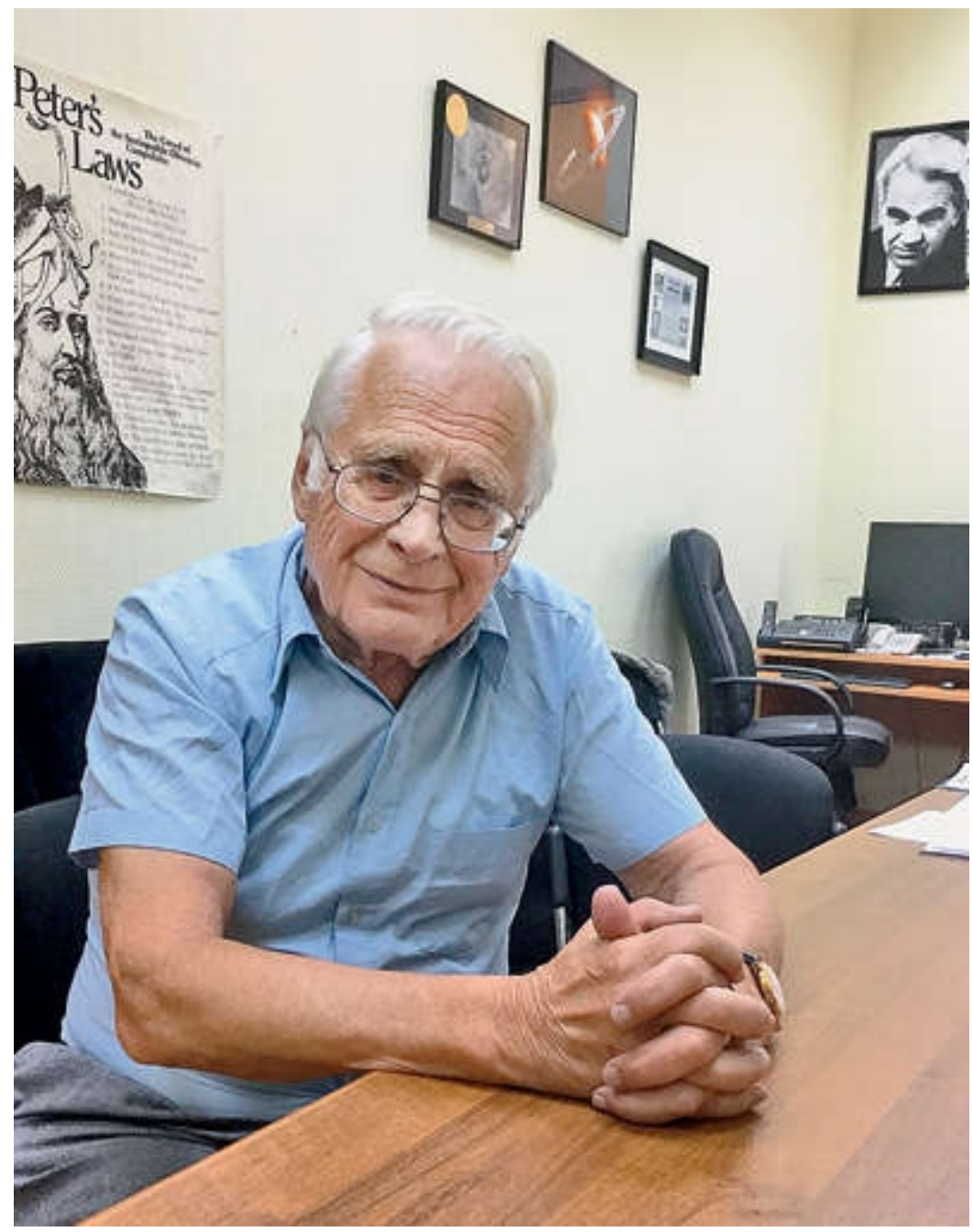

Fig. 1. Academician of the Russian Academy of Sciences Mikhail Yakovlevich Marov 
Mikhail Yakovlevich Marov was born in 1933 in Moscow in a middle-class family (Fig. 2.). His father, a participant in the Great Patriotic War, who was heavily injured, died early. His mother was a teacher at the Moscow Institute of Chemical Engineering. After graduating from a Moscow secondary school in 1952 with a gold medal, Mikhail Yakovlevich enrolled in the Mechanical Department of the Moscow Higher Technical School (now Moscow State Technical University) named after N. E. Bauman (MSTU) that he graduated from with honors in 1958. Mikhail Yakovlevich recalls his university and student's years with a warm feeling, although the time was hard, his mother raised him alone, laying the spiritual, moral foundations of life. He repeatedly said that he was eternally grateful to his parents, who have not only given him the gift of life, but did it very timely indeed, so he graduated from the university just in time - at the beginning of space era. Being a graduate student Mikhail Yakovlevich studied the complex section of mechanics - nonlinear oscillations. Just a few months before receiving diploma, the news of the launch of the first artificial Earth satellite in the USSR came, which shocked him to the core. For the first time he thought about outer space as a tangible entity where he would apply his knowledge, but at that time, this idea seemed an unattainable dream. The real life turned out not a plain sailing.

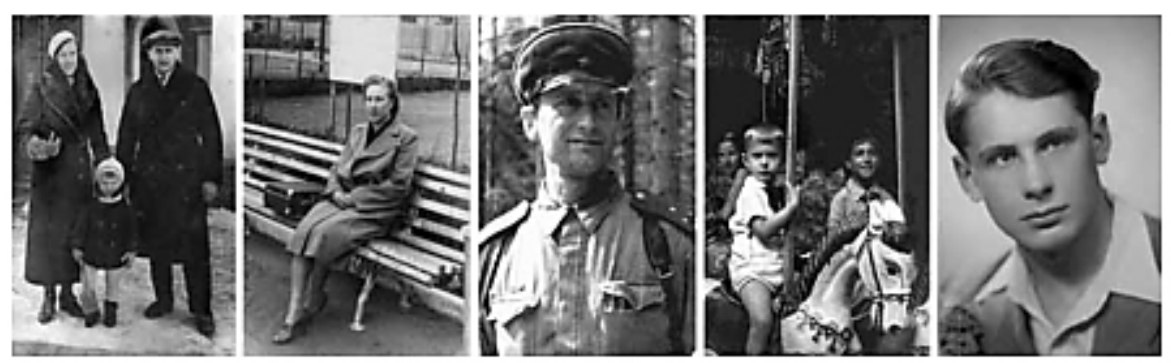

Fig.2. Parents, childhood, youth

The real life turned out not a plain sailing. After graduating from the university Mikhail Yakovlevich has been directed to work at the special state enterprise nearby Moscow. He paid many efforts in order to be engaged in the field close to his university training - non-linear physical processes rather than in routine engineering work. However, application area that he had to deal with was fully new - atomic physics and electronics rather than mechanics, and for two years, he combined hard study of new physical problems with the practical work. The latter was mostly carried out at the A.I. Leipunsky Physics-Energy Institute in Obninsk where Mikhail Yakovlevich spent a lot of time participating in experiments with nuclear reactors for military applications.. Later on he unexpectedly learned that these research were also related to space because in-tended for utilization in spacecraft's onboard energetics for the future interplanetary spacecraft, what Leipunsky Institute pursued following S. P. Korolev's foreseeing. It was therefore his first indirect involvement in space exploration. The second and direct one occurred after reorganization of the industry ventures integrated with the famous ОКБ-1 headed by S. P. Korolev (now the Korolev's Rocketry and Space Corporation (RSC) Energia. The laboratory where Mikhail Yakovlevich worked became a part of the unit for the development of control/orientation systems for space vehicles headed by the prominent scientist academician B.V. Rauschenbach. In the following years, they were connected with warm friendly relations. Mikhail Yakovlevich actively participated in the development of navigation systems of the first interplanetary missions - Mars and Venus 
spacecraft $1 \mathrm{MV}$ and $2 \mathrm{MV}$. Again, everything was new; many problems posed innovative solutions while imperfection of technical means often resulted in annoying errors. Nonetheless, some unique systems were set up in the short conceivable time, largely motivated by the imperatives of the Cold War, by aspiration to surpass the rival and to be the first.

Mikhail Yakovlevich worked enthusiastically, with full dedication of his knowledge and strength. Soon, however, fate drastically changed his life again. By the order of OKB -1 overheads he was nominated an assistant of one of the prominent leaders of the rocket and space industry and Deputy Minister of the State Committee for Defense Technology G.A. Tyulin. For nearly two years he has been closely engaged in the current and future problems of rocketry-space technology, including analysis of emergency rocket launches, under the direct supervision of outstanding industry specialists.

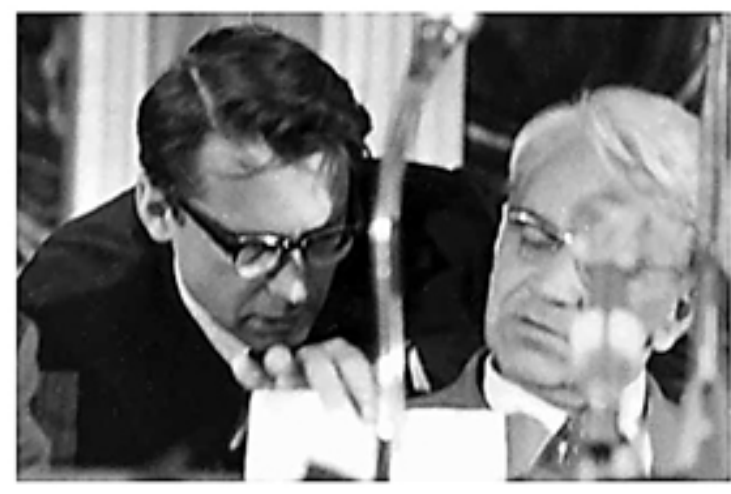

Fig. 3. M.V. Keldysh (right) and M.Ya. Marov, 1971

This period preceded the crucial turning point in his career. At one of the meetings dealing with the Lunar Race Mikhail Yakovlevich got acquaintance with Mstislav Vsevolodovich Keldysh and soon he received an invitation to join his Institute of Applied Mathematics of the USSR Academy of Sciences. Needless to say, Mikhail Yakovlevich accepted this honored invitation with a great joy. For subsequent nearly fifty years his life was tightly connected with this Institute where he really took place as a scientist and made the career from a researcher to a Head of the Department. Either way, the cosmos determined the choice of his life path. This path turned out to be not a simple indeed; there were both dramatic events of loss and finding success of discoveries culminating in recognition of the scientific community. All this was conditioned by the continuous hard work, permanent learning in different scientific disciplines during the whole his life that was driven and moti vated by his curiosity, the wish to push the frontiers of unknown and sincere dedication to science.

\section{SPACE PROGRAMS AND PROJECTS}

A particularly serious school that immeasurably broadened the scientific and technical horizons of Mikhail Yakovlevich and gave him invaluable experience in working with large teams and state projects was his position as the Scientific Secretary of the Interagency Scientific-Technological Council for Space Research (ISTC on SR) under USSR Academy of Sciences auspices, which was headed by M.V. Keldysh (Fig.3.). He occupied this position for about 15 years combining these responsible duties with scientific work in the Institute of Applied Mathematics. He left the position immediately after Mstislav Vsevolodovich passed away in 1978 responding negatively a call to work with other ISTC leaders.

Mikhail Yakovlevich worked in very close relations with M.V. Keldysh throughout nearly twenty years There were the most intense and saturated period of his life, his heydays as he recalls. Mikhail Yakovlevich directly participated in the development of programs of 
scientific and applied space research, discussion and critical assessment of almost all proposed space projects with significant share of his time at space enterprises and rocket launch pads. He had a great opportunity to know personally, closely work together with the leaders of research institutes, and design bureaus including Chief designers of industry members of the famous Counsel of Chief Designers headed by S.P. Korolev.

Among historical people greatly contributing to space exploration Mikhail Yakovlevich distinguish the Chief Designer of S. A. Lavochkin Scientific and Production Association (SPA) G. N. Babakin. He admired this outstanding person whom with he had especially close and friendly relationships, as well as with his deputies, and then successors. This was the venture where spacecraft for planetary exploration were designed and manufactured what stipulated our pioneering successful research of the Moon, Venus and Mars. M.V. Keldysh requested Mikhail Yakovlevich participate personally in the SPA projects development in terms of assistance in solution of fundamentally important scientific problems and related technical issues involving selection of scientific objectives and interfaces of the onboard scientific instruments with spacecraft service systems. He performed for many years the functions of Project Scientist (PS) as such person calls in the West. Mikhail Yakovlevich also undertook his own experiments with some of these spacecraft as a Principal Investigator (PI). M.V. Keldysh supported his experimental research and to facilitate the study he set up a special laboratory in the Marov's Department at IAM. The culmination of this activity became the period from the mid-1960s to the early 1980s - period of the Soviet outstanding pioneering achievements in the exploration of the Moon, Venus, and Mars (Fig. 4-7).

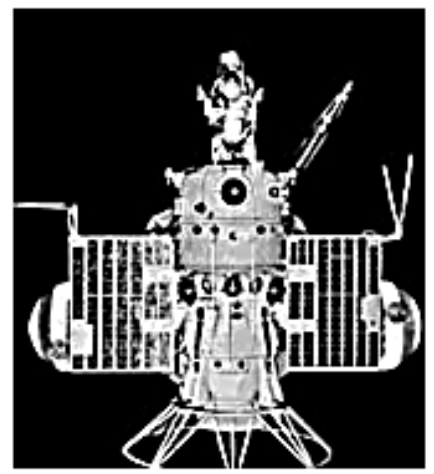

Fig. 4. 2MB - «Mars-1».
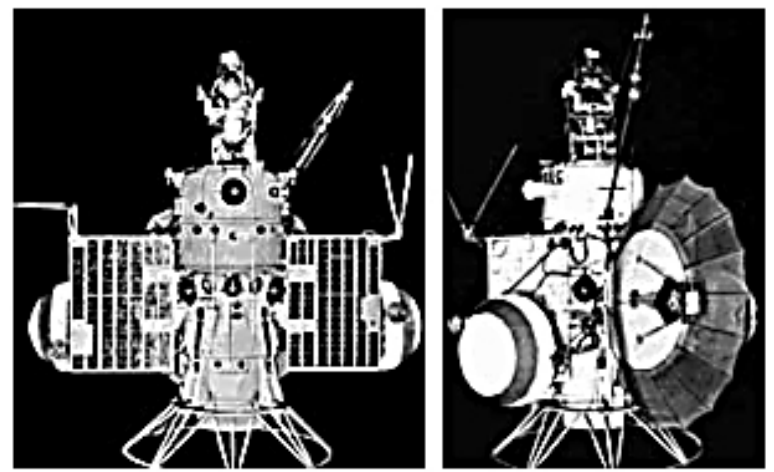

Fig. 6. 1MV - «Marsnik»
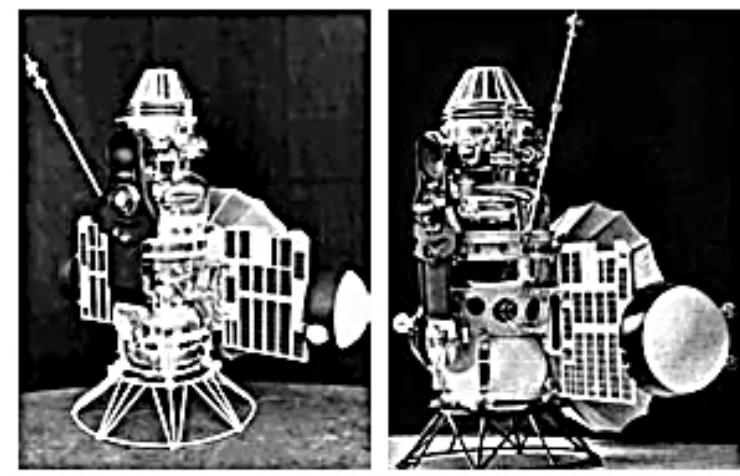

Fig. 5. 2MV - «Venus-2, $-3 »$.
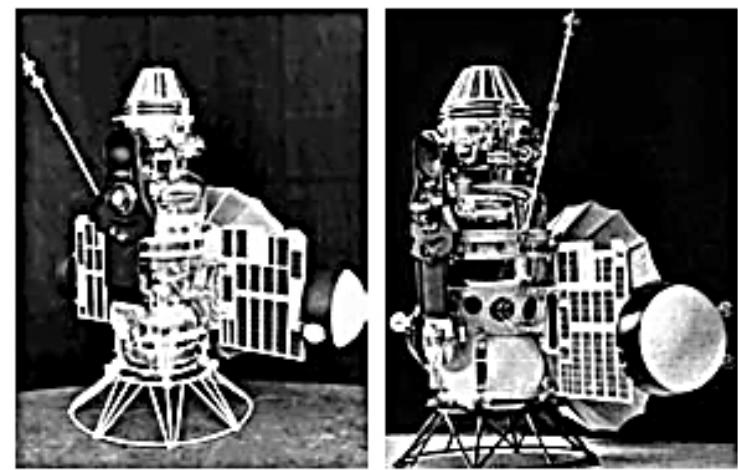

Fig. 7. 1MV - «Venus-1». 
Mikhail Yakovlevich recalls with particular pride the successful multi-year research program of Venus, since the historical launch of «Venera-4» (Fig. 8-10). A lot of time and efforts have been invested to this program including his own, but that was more than rewarded with the excellent technical and scientific results. Successful entry in the Venus atmosphere and parachute descending made possible to derive the first in the world direct measurements of atmospheric parameters of this enigmatic planet. This was followed by the first landings of spacecraft on the planet's surface and their survival in harsh environmental conditions (not repeated by anyone else in the world), illumination measurements and transmission of surface panoramas, measurements of the composition of surface rocks, studying atmospheric dynamics, structure and properties of the Venus clouds, to mention a few the most important.

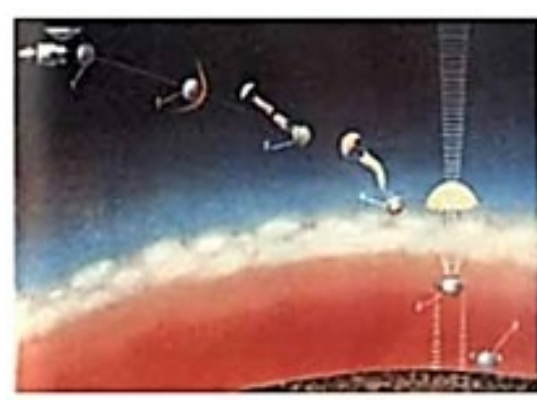

Fig. 8. Entrance descent in the atmosphere («Venus-4»- «Venus-6»)

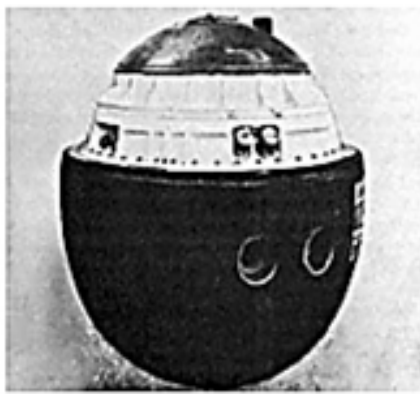

Fig. 10. The descent vehicle, «Venus-7, -8»

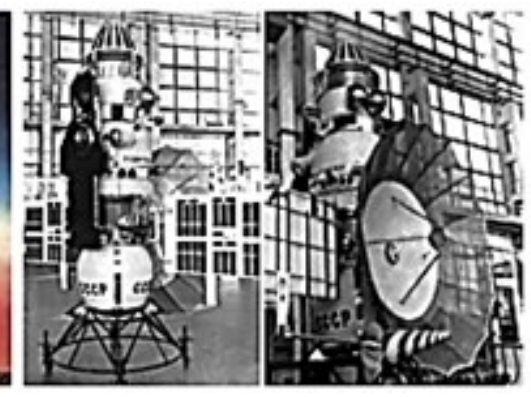

Fig. 9. Spacecraft «Venus-4» - «Venus-6»

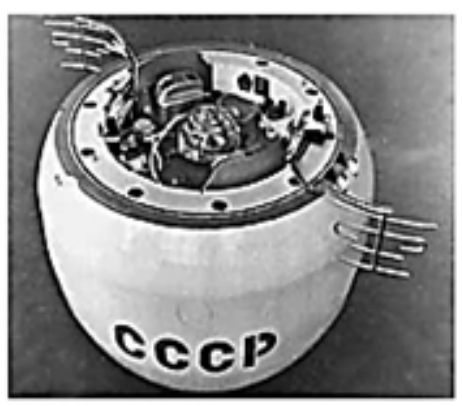

Russian scientists and enginners launched the first artificial satellites of Venus, studied the features of outer space around the planet. These successes were achieved by the two generations of spacecraft created under G.N. Babakin leadership. The second generation, which had a high degree of reliability, also became the technical basis of the «Vega» mission to 1P/Halley's comet and creation of the «Astron» astrophysical satellite.

Unfortunately, not all plans of Venus exploration were implemented. Especially painful to Mikhail Yakovlevich was administrative decision, not justified but adopted in 1981, to cancel the planned launch of the balloon probe for detailed study of the Venus unique clouds and related phenomena, while the project was at the final stage of manufacturing. There was the Soviet-French project led by Mikhail Marov and Jacques Blamont from the Russian and French sides, respectively. Both leaders paid to the project more than three years of their scientific career this turned out a waste of time. 
Less successful was the Russian Martian program, which included artificial Mars satellites and landing vehicles. However, the first soft landing on Mars of the «Mars-3» lander and the first direct measurements of atmospheric parameters with the «Mars-6» lander became outstanding achievements. Mikhail Yakovlevich. and co-workers were proud to contribute to these projects and to obtain the scientific data, which allowed developing the first model of Martian atmosphere from the surface to $\sim 70 \mathrm{~km}$. As the truly epochal are the unique flights of the third generation of lunar spacecraft developed in the Babakin's venture. The automatic lunar soil sampling and return them back to Earth and long-term functioning of self-propelled vehicles (rovers) on the lunar surface were ensured (Fig.11,12). Successful implementation of these projects in the early 1970s allowed us to reduce the negative consequences of losing Lunar Race for landing a first man on the Moon. Mikhail Yakovlevich recalls his complex feelings he experienced watching Neil Armstrong stepping down the Moon surface - a mix of pride for triumph of the human genius jointly with of disappointment and bitterness that it was not Russian.

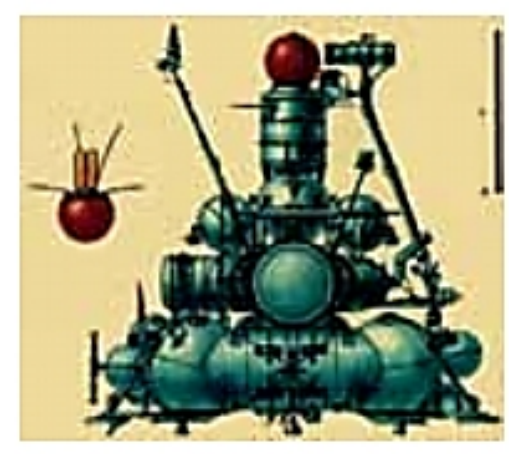

Fig. 11. «Luna 16»

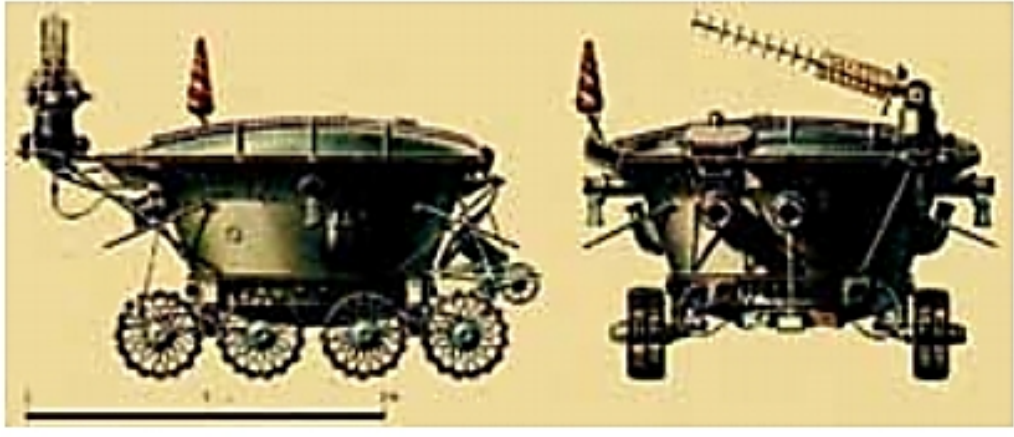

Fig. 12. «Lunokhod-1»

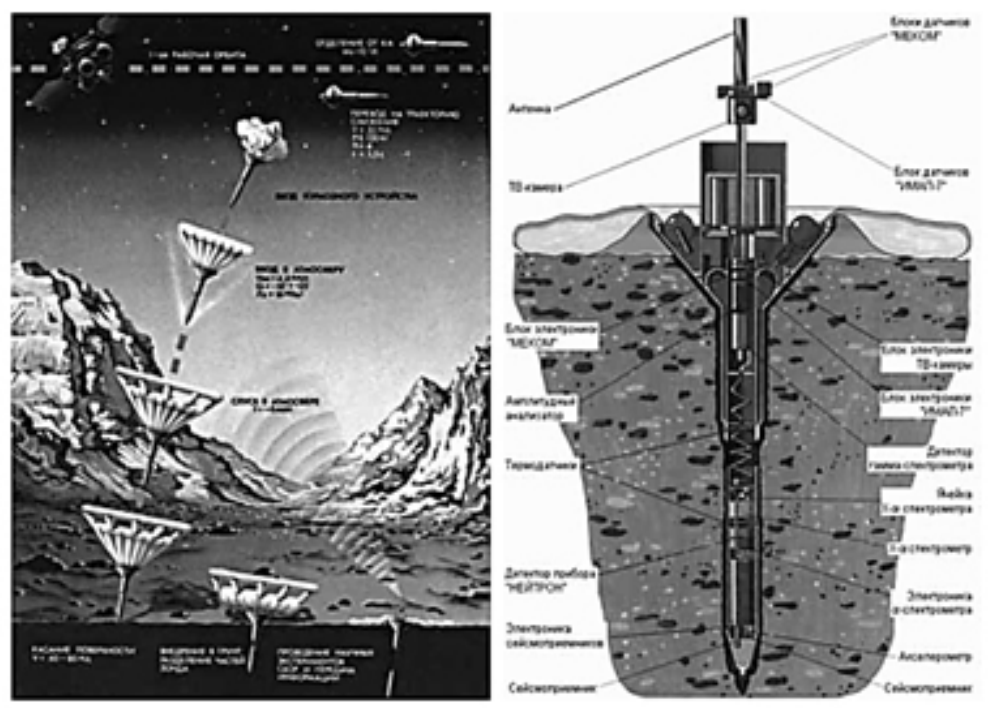

Fig. 13. Launching penetrators to the surface of Mars and the «Mecom» meteocomplex at the top of the penetrator (MARS-96 project) 
It seemed possible to us only eight years after Yuri Gagarin historical flight indeed. S.P. Korolev made a lot to accomplish the goal but his premature death prevented this ambitious plan from happening. Nonetheless, the automatic lunar flights alleviated the bitter situation and kept the country's recognition as a leading space power.

The overall situation fully changed and the former recognition shacked down dramatically in the following decades. While the success of «Vega» missions predetermined the reliability of «Venera» spacecraft, the new developments years after Babakin death turned out much less perfect. This resulted in only partial program performance of the two Phobos- 88 mission and the tragic failure of the Mars-96 launch (Fig. 13). Combined with the devastating effects of perestroika, this has set Russia's lunar and planetary program back decades. Of course, the absence of a leader of such magnitude as M. V. Keldysh had a huge negative impact, none of the subsequent leaders of the space program could not be compared with him, did not have such a colossal authority with the country's leadership.

At the end of the 1970s, after the death of M. V. Keldysh, Mikhail Yakovlevich voluntarily left the INTS on SR and completely switched to scientific work combining theoretical and experimental studies. In the «Vega» project Mikhail Yakovlevich was engaged in calculation of non-gravitational perturbations in the $1 \mathrm{P} /$ Halley comet's motion owing to sublimation of gas and dust from the nucleus surface. The goal was to increase the accuracy of rendezvous of spacecraft with the comet. In the «Phobos-88» mission project he was engaged in the modeling of remote sensing detection of ions ejected by incident laser beam from the moon surface, followed by ions measurements with by mass analyzer on-board instrument «LimaD», in order to determine the Phobos rocks composition. In the «Mars-96» project, he was PI of the meteorological complex installed on penetrators to be jettisoned from the orbiter. The instrument developed with Finland and USA cooperation intended for long-term measurements of Mars atmospheric parameters and variations of dust abundance.

«Mars-96» disaster badly affected the Russian planetary program and aggravated the problems caused by the perestroika. Fortunately, in the late 1990s a small team of enthusiasts with Mikhail Yakovlevich involvement have undertaken heroic efforts to revive the Russian lunar-planetary program. They took into account many changes in the country and in particular in space industry dictated by the new economic interactions and marketing conditions as well as new technologies. Eventually, traditional groups of qualified specialists joined this team. Their joint efforts allowed suggesting the project of the universal planetary spacecraft. They proposed this modern vehicle to undertake «Phobos-Grunt» mission for the ambitious task to return to Earth rock samples from the Mars moon Phobos. Again, Mikhail Yakovlevich invested a lot of time and efforts in this project, which gradually received the state financial support and was included in the Federal Space Program. Its failed launch in November of 2011 literally shocked him and he long time couldn't rid of frustration.

The 20-year period of the Soviet planetary exploration and Mikhail Yakovlevich deep involvement in these historical endeavors is thoroughly reflected in the book «Soviet Robots in the Solar System. Technologies and Discoveries» (Fig. 14,15), written by M.Ya. Marov jointly with his American colleague Wesley Huntress and first published in 2011 in English by Springer-Praxis Publisher in 2011. It was translated in Russian and published by PHIZMATLIT in 2013 (Marov M. Ya., Huntress U. T. Sovetskie roboty v Solnechnoj sisteme. Tekhnologii i otkrytiya) and then in 2018 (2-nd edition). The book objectively describes successes and failures of the Soviet program of lunar-planetary research with automatic spacecraft, and analyzes the causes of unsuccessful launches in the historical 
perspective. By the W. Huntress idea, the sentence: «First on the Moon, first on Venus, first on Mars» on the cover of the book pays tribute to outstanding Soviet achievements in the Moon and planets exploration. The book was awarded the prize of the International Academy of Astronautics for the best book in the fundamental sciences.

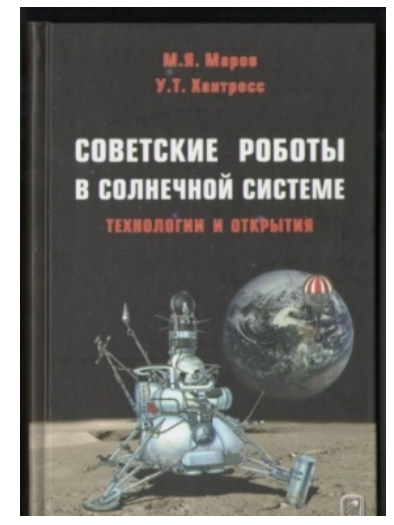

Fig. 14. Edition in Russian

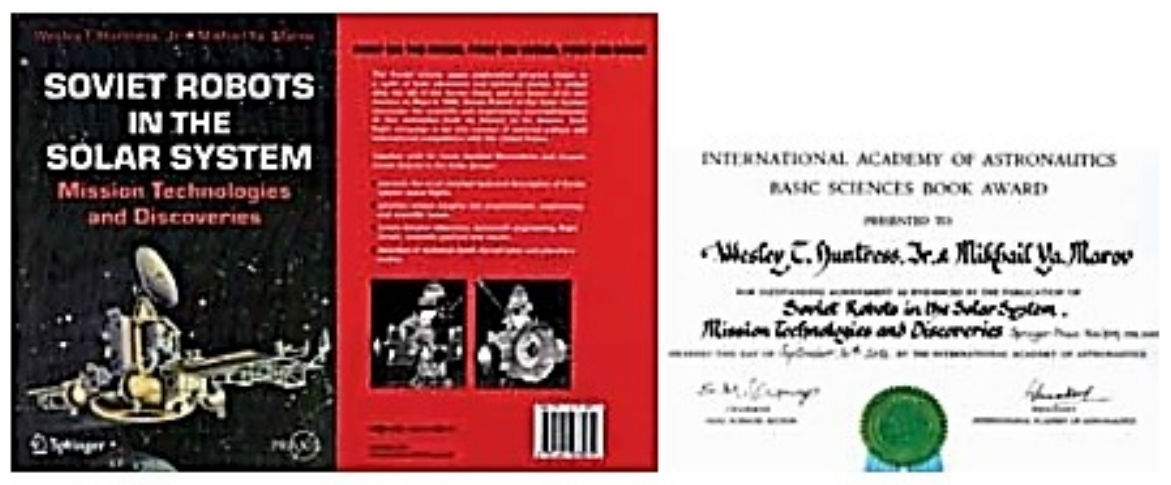

Fig. 15. The book "Soviet robots in the solar systems. Mission technologies and discoveries ", published in 2011 in English by Springer-Praxis, and Diploma of the International Academy of Astronautics for the best book in basic sciences.

Despite the shroud of secrecy behind the USSR space program Mikhail Yakovlevich was known in the West as one of its leaders working closely to the head of the Soviet space program M.V. Keldysh. In addition, M.V. Keldysh assignend Mikhail Yakovlevich to participate in various international events and negotiations and hence he was in spotlight. That is why in 1971, after a successful soft landing of «Mars-3» on the Mars surface Mikhail Yakovlevich was awarded with the International Galaber Prize in Astronautics, which he called the recognition, first of all, of his colleagues from the Lavochkin enterprise. A collage of Brown University (USA), dedicated to him on occasion of 20th anniversary of the «Vernadsky-Brown» symposium, serve as appreciation an of his participation in various space program and projects respected by the foreign scientists (Fig.16).

In 2012 Mikhail Yakovlevich was awarded the NASA Diploma on the occasion of the 50th anniversary of solar system research «in recognition of the leading role in the studies of the solar system and discoveries that changed the world» (Fig. 17). In 2013, he got the famous Alvin Seiff Award «in recognition of the outstanding and unique contribution to planetary studies, including the first direct measurements in the atmospheres of Venus and Mars»(Fig.18).

The book "Soviet robots in the solar systems. Mission technologies and discoveries", published in 2011 in English by Springer-Praxis, was awarded the Diploma of the International Academy of Astronautics for the best book in the field of basic sciences. In 2013, it was released in Russian by the Publishing House of Physical and Mathematical Literature. 


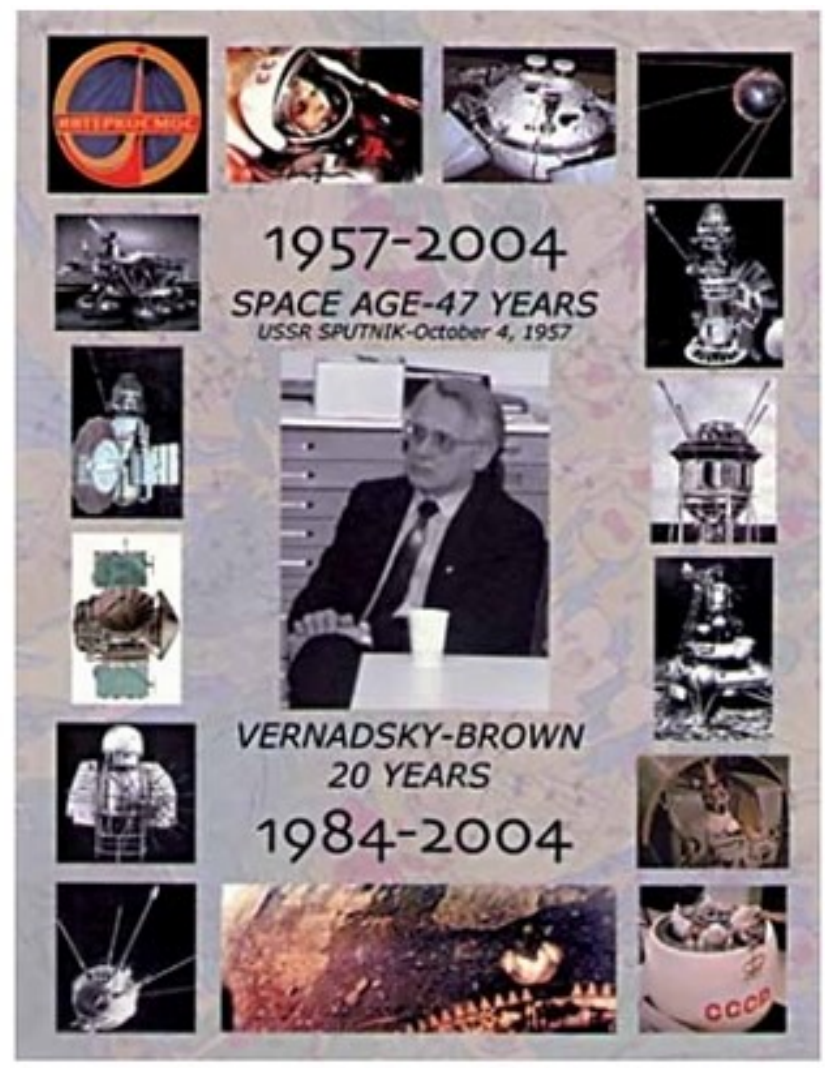

Fig. 16. Collage of Brown University (USA), awarded to the author in connection with the 20th anniversary of the symposium «Vernadsky - Brown».

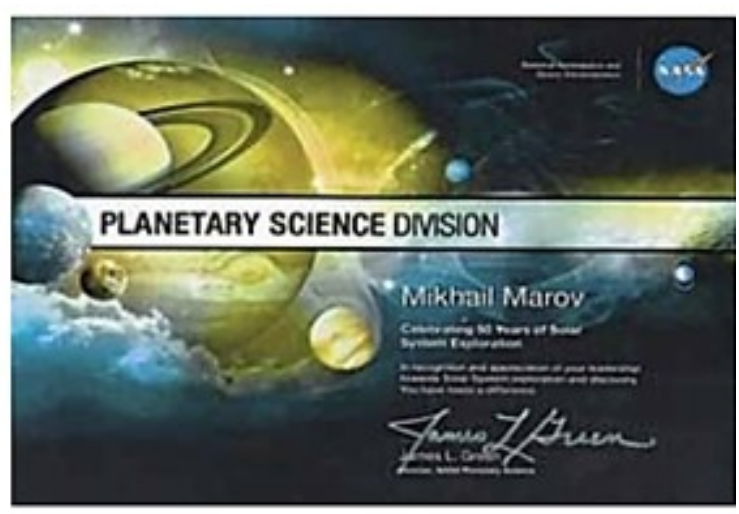

Fig. 17. A NASA diploma on the occasion of the 50th anniversary of the exploration of the solar system «in recognition of the leading role in the exploration of the solar system and the discoveries that have changed the world».

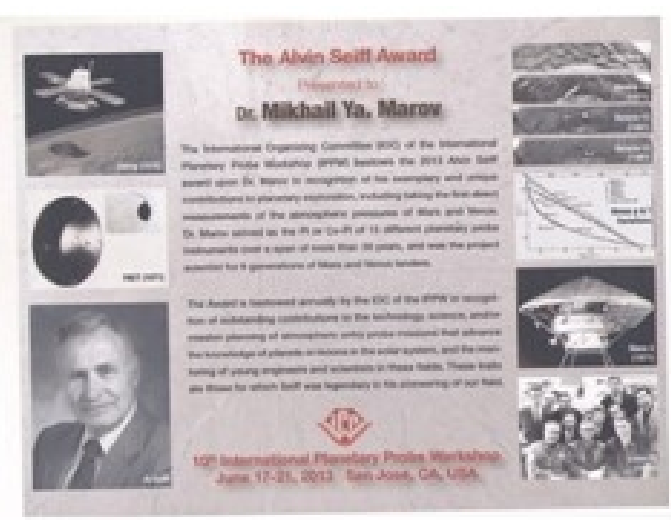

Fig. 18. Alvin Siff Award for Planetary Research. 


\section{SCIENTIFIC RESEARCH}

In parallel with the work in STC, Mikhail Yakovlevich headed the Department of Mechanics, Planetary Research and Aeronomy at the IAM, leading theoretical and experimental studies. Integration of these duties was not a simple task and required tremendous dedication and energy concentration. Mstislav Vsevolodovich supported and directed the scientific activities of this unit, helped in solving a number of theoretical problems. In1964, Mikhail Yakovlevich defended his Ph.D., and in 1970 he received a full doctor's degree in the field of physics and mathematics sciences. In 1977, he awarded the title of Full Professor, and in 1990 elected a corresponding member of the USSR Academy of Sciences in the Division of Mechanics and Control Systems. He elected a Full Member (Academician) of the Russian Academy of Sciences in the Earth Sciences Division in 2008. These events reflected the recognition by the Academy members the importance of Mikhail Yakovlevich contribution to space and planetary sciences including their value for Earth as one of the Solar System planets.

The scientific legacy of Mikhail Yakovlevich research that he made personally and jointly with his pupils and colleagues could be divided into the following sections:

1. Physical mechanics, hydrodynamics and physical kinetics, aeronomy, mathematical modeling of space and natural environments The main colleagues and co-authors: Prof. A. V. Kolesnichenko, Corr. Member of RAS D.V. Bisikalo, Dr. V.I. Shematovich, Dr. A.M. Alferov, Dr. O.P. Krasitsky).

2. Planetary research with spacecraft, direct in situ measurements, development of models based on the experimental data(Principal colleagues and co-authors: Academician RAS V. S. Avduevsky, Dr. M. K. Rozhdestvensky, Prof. V. I. Polezhaev, Dr. F.S. Zavelevich, Dr. V. V. Kerzhanovich, N. F. Borodin, Dr. Yu. P. Karpeisky, Dr. B.E Moshkin, Dr. A.P., Economov, Dr. Z.P. Cheremukhina, K.K., Manuylov, Dr. V.P. Osipov, Dr. V.P. Shalimov and M.Z. Mukhoyan).

3. Planetary cosmogony and cosmochemistry, the origin and evolution of the solar system and other planetary systems (exoplanets) (The main colleagues and co-authors: Prof. A.V. Kolesnichenko, Dr. V.A. Dorofeeva, Dr. A.V. Rusol, Dr. A.B. Makalkin, Dr. S. I. Ipatov, Dr. I.M. Ziglina).

We are not going to discuss even the most significant results obtained by Mikhail Yakovlevich. in each of these sections. The detailed contents of his research can be find in his numerous papers and monographs written by himself and/or together with colleagues.

\subsection{Mechanics of reacting gases, turbulence of inhomogeneous media, aeronomy, kinetics of non-equilibrium processes, mathematical modeling space environment}

The section deals with specific approach of classic mechanics and gas kinetics used for specific problems of space environment modeling. This is the area where Mikhail Yakovlevich worked for almost half a century. He initiated the study of many «unknowns» with application of some basic methods of multicomponent radiative hydrodynamics, turbulence of inhomogeneous reacting media, dynamics of a rarefied gases, and physicalchemical kinetics. They paved the road to the development of the new branch of space research - planetary aeronomy, which he began to study as a postgraduate under the guidance of Professor V. I. Krasovsky. A part of these studies was inverse problems solution: deducing temperature/density of the Earth's upper atmosphere and their variations depending on the 
solar and geomagnetic activity from the measured data of evolution of the artificial Earth satellites orbits. At the same time, together with his first student and then colleague A.V. Kolesnichenko, Mikhail Yakovlevich began to develop the theoretical foundations of aeronomy. The key of the problems involved in the field of rarefied gas dynamics is the direct exposure of the upper atmosphere gas to energetic solar electromagnetic and corpuscular radiation accompanied by the reactions of photolysis (dissociation, ionization, and excitation) and the numerous direct and inverse transitions - chemical reactions, together with heat and mass transfer and diffusion processes. Based on these complex studies, he developed the first models of the Earth's upper atmosphere used for accurate prediction of the lifetime of satellites and orbital stations. The results also contributed to refining CIRA - the International Reference Model compiled by the Committee on Space Research (COSPAR)). Models of ozone content variations depending on small species and turbulence were also studied in framework of the European space project GOMOS (Global Ozone Monitoring by Occultation of Stars).

Another area of aeronomy research was focused on the study of nonequilibrium kinetic processes in the rarefied gas of the upper atmospheres of Earth and other planets. These studies were started by Mikhail Yakovlevich with his other talented student V.I. Shematovich, who later successfully used the developed methods to solve the problems of astrochemistry. The basis was laid on the methods of stochastic modeling when solving the Boltzmann type equations with the right-hand side containing reaction integrals. The method made possible to take into account with a good accuracy the contribution of solar radiation and chemical sources of heating in the energy budget, as well as an efficiency of dissipation of atmospheric atoms into outer space. Original physical-probabilistic analogue of the the Boltzmann kinetic equation was constructed in the form of a random process of particle interactions/relaxations in Markov's form with the use of Monte Carlo algorithms for the numerical evaluation. Methods of statistical modeling have been successfully utilized in the study of nonequilibrium state of some Earth's upper atmosphere components with the account for ionization rate of $\mathrm{O} 2, \mathrm{~N} 2$ and $\mathrm{O}$, kinetic energy spectra and distribution functions of «hot» oxygen and nitrogen atoms due to photo dissociation at different heights, and spectra of kinetic energy of photoelectrons. Application of this approach to Mars allowed us to estimate the rate of water loss due to non-thermal dissipation of heavy atoms from the planet's atmosphere. The role of water in the evolution of the ancient Martian atmosphere also studied with the analysis of contribution of photolysis and chemical reactions.

This segment of Mikhail Yakovlevich scientific research also includes modeling of the structure and composition of the comet's internal coma, with a detailed study of the processes of molecular transport in the porous core, sublimation of gas and dust from the surface of the icy nucleus, and the formation and radial profiles of macro-parameters near the surface in the Knudsen layer. These models were developed jointly with V. Shematovich, D. Bisicalo, V. Strelnitsky. Together with A. V. Kolesnichenko he assessed an influence of non-gravitational perturbations on the motion of the Halley comet at different distances from the Sun. These results were used in the VEGA project for the spacecraft navigation. They also assessed the displacement of the observed «photometric» nucleus because of light scattering by dust relative to the physical one in order to point cameras and other onboard instruments correctly.

In the set works of M.Ya. Marov on the mechanics of space and natural environments, a special place occupied the studies jointly with A. V. Kolesnichenko on the complex problems of turbulence of multicomponent reacting gases. They carried out these researches including 
the fundamental theoretical approaches, the respective mathematical apparatus, methods of setting and solving model problems for almost three decades and continue to develop the study successfully. The results are summarized in the numerous publications and a number of monographs published by leading Russian and foreign publishers («Nauka», «Phyzmatlit», «Binom», «Kluwer Academic Publishers» and «Springer») [1-16]. These studies focused on space applications, mostly on the problems of cosmogony, an evolution of gas-dust accretion disks. We emphasize that in the works a new direction in the studies of inhomogeneous turbulent media has emerged, involving thorough analysis of chemical reactions between gas components and dust influence in the heterogeneous medium. No less important is consideration of the hydrodynamic helicity and the efficiency of dust clusters formation in turbulent vortices because of streaming instability in the hydrodynamic flow.

\subsection{Planetary space research, development of models based on the data of measurements}

This large part of the Mikhail Yakovlevich scientific research is mostly related to the experimental studies with the planetary vehicles. He obtained the most important results in the study of Venus with the spacecraft «Venera-4» - «Venera-14» (1967-1981). Together with his colleagues, he had the unique chance to investigate an enigmatic Venus atmosphere and to carry out the world's first direct measurements of its parameters. "Venera-4» was the first vehicle that discovered the atmospheric properties while «Venera-7» and «Venera-8» landers reached the planet's surface and successfully operated in a very harsh environment. The second generation of more capable «Venera-9-14» landers and satellites made possible to unravel many mysteries of the Venus nature. In the height profiles of his more accurate temperature and pressure measurements, he found some inhomogeneity he associated with convection in the Venus lower atmosphere. He studied the peculiar features of the global atmospheric dynamics from the data of Doppler shift measurements of transmitters' master oscillator frequency during the landers descending, as well as by the direct wind speed measurements on the Venus surface with anemometers. As the result, the height profiles of the wind velocity from the surface to upper cloud deck were found, which confirmed an existence of atmospheric superrotation. In addition, for the first time in the world, he and his colleagues measured the solar radiation attenuation with height in several spectral ranges in the atmosphere and illumination on the surface and concluded that red rays predominate at the Venus surface giving it an orange tint. Thus, being on the Venus surface you would see orange skies over your head. These measurements made it possible to transmit first black-andwhite, and then color panoramas of the surface, as well as to obtain the first data on the location and structure of the Venus clouds. Mikhail Yakovlevich studied in detail the structure and microphysical properties of the clouds with the nephelometer technique on the «Veneras9 and 10» landers. For the first time, he discovered the three main cloud layers and transition zones in between consisting of three modes of micron-sized particles with different refractive indices. This led to the conclusion that particles of the clouds are completely different from water ice and formed by a substance of different nature, which later on was identified with concentrated sulfuric acid. In addition to the main layered cloud deck located between 49 and $68 \mathrm{~km}$ above the surface, he and co-workers revealed the presence of sub-cloud (at 49 to 35 $\mathrm{km}$ ) and upper cloud (above $68 \mathrm{~km}$ ) hazes. The state of art results of Venus study were 
described in the book after M.Ya. Marov and D. Grinspoon «The Planet Venus» published by the prestigious Yale University Press.

M.Ya. Marov paid the great attention to the Venus and Mars atmospheres modeling which based, on his own measurement data. He developed the first model of the Venus atmosphere based on the temperature, pressure and chemical composition data and the detail analysis of thermodynamic properties of the atmospheric gas. He worked on the problems of radiative heat transfer and atmospheric dynamics attempting to explain the formation of runaway greenhouse responsible for the unusual Venus climate. Unfortunately, only limited data were derived from the direct measurements of altitude profiles of temperature, pressure and horizontal wind velocity from the «Mars-6» lander. Nonetheless, based on these data the Martian atmosphere he and colleagues created Mars atmosphere model that was in a good agreement with the subsequent more complete measurements on the American landers «Viking». These studies stimulated Mikhail Yakovlevich to develop meteorological complex installed on penetrators of «Mars-96» mission and later the methodology and instrument "Thermophobe» intended to measure thermal characteristics of Phobos surface with the «Phobos-Grunt» lander. This device serves as precursor of «Thermo-L» instrument for similar measurements on the lunar surface that installs on the «Luna Resource» lander.

Finally, it is worth to mention about the Mikhail Yakovlevich work on the problems of mechanics of weightlessness, in which he actively participated for several years along with V.S. Avduevsky, V.P. Osipov and their colleagues. He studied deeply enough this new advancing area of space research and published a few joint scientific papers that witness extremely broad areas of his scientific interests.

\subsection{Planetary cosmogony and cosmochemistry - origin and evolution of the solar system and planetary systems around other stars (exoplanets)}

The area of research, which Mikhail Yakovlevich focused on over the past two decades, is genesis of planetary systems. This branch of astrophysics known as planetary cosmogony is going back in time to middle centuries and rooted in Kant-Laplace basic ideas about an origin of the solar system. However, it took a great impetus only in the latest time when observations of circumstellar disks with the modern astronomical instruments became available, and also owing to discovery of exoplanets and relevant mathematical modeling with the use of powerful computers. Direct analysis of extrasolar matter encapsulated in its structure and composition and allowing to reconstruct the original processes of chemical reactions, phase transitions, etc. nicely complement the studies.

As the basic theory is concerned, the field combines different sections of physical mechanics from which the modern branch of mechanics of space and natural media has emerged. The modeling methods covered by planetary cosmogony involve the problems of heat and mass transfer, turbulence, and physical kinetics, to mention a few. They are closely related to aeronomy and most recently appeared cosmochemistry. The latter is the great tool allowing us to limit some constraints imposed on mathematical models when incorporating data on the structure, chemical-mineralogical composition and isotopic ratios of characteristic elements of meteorites matter. It therefore makes possible to reconstruct the processes of origin and evolution of celestial bodies and planetary systems as a whole more reliably. Vernadsky Institute is the world-recognized holder of excellent collection of meteorites including falls from the Moon and Mars, as well as lunar soil delivered by space vehicles. 
This provides a synergy in the use of two approaches in the models development and in particular, it motivated Mikhail Yakovlevich to changing affiliation in order to advance the cosmogony problems through such a synergy. Currently, he and colleagues focuses on modeling the early stages of thermal and dynamical evolution of gas-dust turbulent accretion disk from a fragment of molecular cloud based on the mechanics of heterogeneous media with the account of magnetohydrodynamic (MHD) effects. They also pay significant attention to the analysis of gravitational and hydrodynamic disk instabilities resulted in disk fragmentation into fluffy clusters of fractal nature followed by their collisional interactions and growing inhabited dust particles from nanometers to pebble-boulder sizes and eventually to planetesimals.

Mikhail Yakovlevich published numerous papers and a number of monographs on the subject of stellar-planetary cosmogony that, likewise his earlier books, took national and international recognition. Among them, the monographs written with Prof. A. V. Kolesnichenko on the problems of turbulence and self-organization are to be distinguished. In these books, authors specially address the problem of turbulent accretionary discs instabilities and ordered structures formation at the originally chaotic background. In other words, following Yu. L. Klimontovich, they consider an orderly organized turbulent flow against the chaotic background. This topic is in close relation with general analysis of the behavior of chaotic systems what Mikhail Yakovlevich studied jointly with Acad. A.M. Friedman and they edited together a few published books.

Since the 1990s, Mikhail Yakovlevich studied migration processes in the solar system. In colloboration with S. Ipatov he developed the model of icy small bodies and dust particles migration from the outskirt of the solar system (Kuiper belt) involving their intermediate capture into orbits intersecting that of Jupiter followed by inward drift to orbits of the main asteroid belt and then fullfilling Amour-Apollo-Aten (NEO) group approaching the terrestrial planet orbits and thretened Earth. The corollary of the model is the conclusion that at the stage of intense bombardment by comets and asteroids of carbonaceous chondrites type with large water and other volatiles abundance (LHB) Earth could receive by the mechanism of heterogeneous accretion, an amount of water comparable to its content in the Earth's oceans. Tis could could compensate for the loss of volatiles at the Earth formation stage and is closely related also to the problem of the biosphere origin. Venus and Mars would receive comparable amounts of exogenic water, which reinforces the hypothesis of an existence of their ancient oceans lost in the course of subsequent evolution $[4,6,9,11]$.

\section{INTERNATIONAL COLLABORATION, PEDAGOGICAL AND OUTREACH ACTIVITY}

The professional activity of Acad. M.Ya. Marov was tightly connected with international cooperation culminated during the period of his working at the STC. Since early 1960s he was a part of the Commission for Exploration and Use of the Outer Space (which was an open body of the secret STC) chaired by Acad. A. A. Blagonravov. In 1965, Acad M.V. Keldysh recruited Mikhail Yakovlevich to the new created Intercosmos Council responsible for the USSR international cooperation with socialist countries camp and later on with France. He continued this activity for many years. Since that time he began to travel abroad to participate in various conferences and symposia. Scientific community elected as a member and/or head of a number of commissions and working groups in the international scientific organizations 
such as Committee on Space research (COSPAR), International Astronautical Federation (IAF), International Association of Geomagnetism and Aeronomy (IAGA), International Association of Meteorology and Atmospheric Physics (IAMAP). He was elected President of the Commission and then President of the Division III (Planetary Research) of the International Astronomical Union (IAU). Mikhail Yakovlevich has established friendly relations with many outstanding foreign colleagues. Among them, there were Carl Sagan, Thomas Gold, Tobias Owen, James Pollack, Gordon H. Pettengil, William Irvine, Brad Smith, Harold Masursky, Gerry Soffen, Mikhael Carr, Stiff Saunders, Jacques Blamont, James Head, Wesley Huntress and many others.

In 1971, USSR and USA signed the first Agreement on cooperation in outer space. From the Soviet side the document signed President of the USSR Academy of Sciences M.V. Keldysh and from the American side First Deputy of NASA Administrator George David Low who headed US delegation visiting Moscow. Four Joint Working Groups (JWG) were set up: Outer space, the Moon and planets; Space meteorology; Space communication; Space biology and medicine. M.Ya. Marov NASA Assistant Director Noel Hinners were nominated the co-chairs of the first JWG, which worked actively for about seven years until Reagan administration came to power. In particular, direct link (tele bridge) was established during Soviet and American Mars missions for the real time coordination of observations and scientific data exchange, with Mikhail Marov and Gery Soffen on the both sides. Mikhail Yakovlevich actively participated in international cooperation on some other space projects, including «Phobos-Grunt» and the planned «Luna» missions.

Mikhail Yakovlevich has a great experience in teaching. He gave lecture courses and served an advisor for $\mathrm{PhD}$ students, training above 20 candidates and doctors of science. Since 1989, he was deeply involved in educational programs of the new created International Space University (ISU) where he taught annually for 30 years serving as Head of Physical Sciences Department, Lecturer and a member of Academic Council and Board of Trustees. The university graduates future leading specialists in the field of space exploration on the international, interdisciplinary and intercultural (3I) basis using brain storming approach. Mikhail Yakovlevich contributed in the ISU activity including both permanent campus in Strasbourg (France) and summer sessions programs running over the world, and this his activity was highly appreciated. In 1994-1995, he has been teaching at the University of North Carolina working also on space projects. He is Professor of the M.V. Lomonosov Moscow University and he currently lectures at the Department of Space Research.

Throughout many years Mikhail Yakovlevich dealt with the scientific-organizing duties. Besides the above-mentioned activity in the STC and numerous international bodies, he worked and keeps working in the different commissions, committees, and councils. Currently he is a member of the Bureau of the Outer Space Council of the Russian Academy of Sciences (RAS); Chairman of the RAS Commission on K.E. Tsiolkovsky Scientific Heritage; vicechairman of the RAS Scientific Council on Astrobiology; Member of the Expert Commission for promotion of scientific knowledge and Scientific Awards for the best works on popularization of science. He chairs the permanent workshop in the Vernadsky institute. For more than 3o years he is Editor-in-Chief of the international scientific journal «Astronomicheskij vestnik. Issledovanija Solnechnoj sistemy» (Solar System Research) issued simultaneously in Russian and English, and had been a member of Editorial boards of several international scientific journals. Since 2009, UNESCO World Heritage Committee (WHC) involved him in the astronomy-space heritage activity aimed to perpetuate the most 
recognized space-rocket centers and space objects, which expanded tremendously the boundaries of our knowledge. He chaired the tentative Task Group since 2012 to initiate the process of space science and technology commemoration.

Mikhail Yakovlevich has published about 300 scientific papers in the referred journals and 18 monographs with the world-recognized domestic and foreign Publishers [1-16]. He also pursues his permanent outreach activity popularizing science through publications and TV programs. He is an author of the most recognized popular books «Planets of the solar system» (NAUKA PH, 1981 1-st and 1986 2-nd editions) and «Kosmos. From the solar system to the core of the Universe» (PHYSMATLIT, 2016 1-st and 2018 2-nd editions).

M.Ya. Marov was elected a full member of the International Academy of Astronautics, a member of the British Royal Astronomical Society. He has several distinguish state and international awards. He is laureate of the most distinguished Lenin Prize and the USSR State Prize. His Governmental awards include Order of the Labor Red Banner, Order of Honor, Order of Friendship and medals. Most recently he was awarded with the distinguish Demidov Prize and Keldysh Gold Medal of RAS for outstanding achievements in science. Among his international awards are prestigious Galabert Prize for Astronautics, Edwin Sieff Award, and COSPAR Nordberg Medal.

\section{GREAT TEACHER M.V. KELDYSH}

In conclusion, we would like to emphasize once again that Mikhail Yakovlevich Marov had the happy fate to be in the very core of many historical events and to share outstanding space achievements in the great country - Soviet Union.

He joined this enterprise when humans just only began to study space and master it. He was happy to work productively in his lovely field of science and create his scientific school. He was fortunate to know personally many wonderful people dedicated to space exploration and pioneering discoveries the world beyond the home planet. Mikhail Yakovlevich warmly

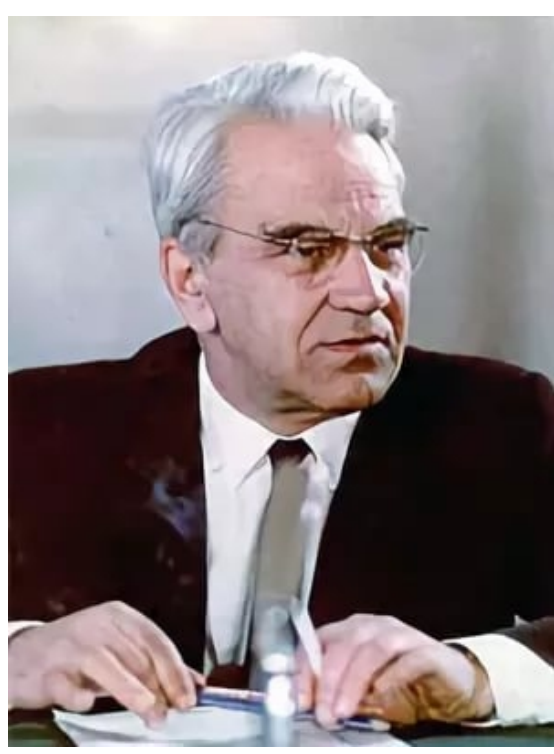

Fig. 19. The great teacher M.V. Keldysh reminds many of them whom with he was fortunate to be on a short stretch of space and time donated to a human by nature. He especially distinguish and esteem, however, the real leader of space breakthroughs, his Great Teacher Mstislav Vsevolodovich Keldysh. He speaks of him with a mix of infinite respect and admiration. From his teacher Mikhail Yakovlevich took many lessons learned in science and management and - most importantly - perceived his life philosophy and world attitude. He address the relationships with this amazing scientist and personality as a great gift of his fate.

The above biography of Mikhail Yakovlevich Marov is essentially a brief overview of what he has accomplished, and not in pursuance of official orders, but motivated by his own choice and mental capacities. Earlier telling about the main directions and issues of his scientific and scientificorganizational work, we already mentioned that many outcomes of this activity and the results of research of the scientist have been described in the numerous published 
books and monographs. There is, however, one of them that he especially values. This is the unique book «Space Research» (M.V. Keldysh, M.Ya. Marov. «Kosmicheskiye Issledovaniya. M.:Nauka. 1981») based on a paper of the same title written by him jointly with his great teacher for the Proceedings «October and Science» («Oktyabr anf Nauka») and published by Nauka PH by the 60-th anniversary of October revolution in 1977.

Needless to say, Mikhail Yakovlevich feels proud of M.V. Keldysh invitation to co-author him in this work. Discussions in due course of writing the manuscript left the deep trace in his memory.

Colleagues congratulate Mikhail Yakovlevich on his remarkable anniversary and wish him many more years of active life and fruitful activity.

\section{REFERENCES}

[1] A.D. Kuz'min, M.Ya. Marov, Fizika planety Venera, M.: Nauka, Gl. red. fiz.-mat. lit., (1974).

[2] M.V. Keldysh, M.Ya. Marov, Kosmicheskiye issledovaniya, M.: Nauka, (1981).

[3] M.Ya. Marov, Planety Solnechnoy sistemy, M.: Nauka, (1986).

[4] M.Ya. Marov, A.V. Kolesnichenko, Vvedeniye v planetnuyu aeronomiyu, M.: Nauka, (1987).

[5] M.Ya. Marov, V.I. Shematovich, D.V. Bisikalo, Kineticheskoye modelirovaniye razrezhennogo gaza $v$ zadachakh aeronomii, Izd.-vo: M.: IPM im. Keldysha AN SSSR, (1990).

[6] A.V. Kolesnichenko, M.Ya. Marov, Turbulentnost' mnogokomponentnykh sred, M.: MAIK «Nauka», (1998).

[7] M.Ya. Marov, D. Grinspoon, The Planet Venus, Yale University Press, (1998).

[8] M.Ya. Marov, "Malyye tela colnechnoy sistemy i nekotoryye problemy kosmogonii", UFN, 175(6), 668-678 (2005).

[9] M.Ya. Marov, A.V. Kolesnichenko, Mechanics of turbulence of multicomponent gases, Kluwer Academic Publishers, Dordrecht, Boston, London, (2001).

[10] Sovremennyye problemy mekhaniki i fiziki kosmosa. K 70-letiyu so dnya rozhdeniya chl.korr. RAN M.Ya. Marova, (Eds. V.S. Avduyevskogo, A.V. Kolesnichenko), M.: Fizmatlit, (2003).

[11] M.Ya. Marov, A.V. Kolesnichenko, Turbulence and Self-Organization, Modeling Astrophysical Objects, Springer. (2013).

[12] W.T. Huntress, M.Ya. Marov, Soviet Robots in the Solar System. Mission Technologies and Discoveries, Springer -Praxis (2011).

[13] M.Ya. Marov, W.T. Huntress, Sovetskie roboti v Solnechnoy sisteme, Fizmatlit, 2-oe izd., (2018).

[14] M.Ya. Marov, Kosmos. Ot Solnechnoy sistemy vglub' Vselennoy, M.: Fizmatlit, 2-oe izd., (2018).

[15] M.Ya. Marov, I.I. Shevchenko, Ekzoplanety, Institut komp'yuternykh issledovaniy, (2017).

[16] V.I. Shematovich, M.Ya. Marov, "Dissipatsiya planetnykh atmosfer: fizicheskiye protsessy i chislennyye modeli”, UFN, 188(3), 233-265 (2018).

Received May 20, 2019 


\title{
КОСМОС - ЭТО СУДЬБА: ИССЛЕДОВАНИЕ СОЛНЕЧНОЙ СИСТЕМЫ.
}

\author{
ПО СЛУЧАЮ 85-ЛЕТИЯ АКАДЕМИКА РАН М.Я. МАРОВА
}

\author{
Б.Н. ЧЕТВЕРУШКИН ${ }^{1}$, А.И. АПТЕКАРЕВ ${ }^{2}$, А.В. КОЛЕСНИЧЕНКО ${ }^{3 *}$, \\ В.И. МАЖУКИН ${ }^{4}$ В.П. ОСИПОВ \\ ${ }^{1}$ Научный руководитель ИПМ им. М.В. Келдыша РАН, академик РАН, профессор, \\ Москва, Россия \\ 2 Директор ИПМ им. М.В. Келдыша РАН, член-корр. РАН, профессор, Москва, Россия \\ ${ }^{3}$ Главный научный сотрудник ИПМ им. М.В. Келдыша РАН, профессор, Москва, Россия \\ ${ }^{4}$ Главный научный сотрудник ИПМ им. М.В. Келдыша РАН, профессор, Москва, Россия \\ ${ }^{5}$ Ведущий научный сотрудник ИПМ им. М.В. Келдыша РАН, Москва, Россия \\ *Ответственный автор. E-mail: kolesn@keldysh.ru
}

DOI: $10.20948 /$ mathmontis-2019-46-15

Ключевые слова: Механика сплошных сред, неравновесные кинетические процессы, исследования планет и космогония.

\begin{abstract}
Аннотация. Статья посвящена 85-летию выдающегося Российского учёного, действительного члена Российской академии наук Михаила Яковлевича Марова. Академик М.Я. Маров советский и российский физик и астроном, ведущий российский ученый в области теоретического и экспериментального изучения Солнечной системы, сравнительной планетологии, математического моделирования природных и космических сред. Ему принадлежат выдающиеся пионерские результаты исследований Венеры и Марса, которые получили широкое мировое признание. Впервые в мире им выполнены прямые измерения температуры и давления на поверхности Венеры и Марса, проведены исследования теплового режима Венеры, динамики атмосферы, структуры облаков. Он сыграл ведущую роль в решении сложной задачи посадки наших аппаратов на поверхность Венеры, благодаря чему удалось передать на Землю цветные панорамы, измерить элементный состав пород. Он непосредственный участник реализации программ «Луна», «Венера», «Вега», «Марс», «Фобос».

Область научных интересов М. Я. Марова очень широка. Она включает механику и физику космоса, астрофизику, планетологию, математическое моделирование космических сред. Он внес большой вклад в развитие наших знаний о космической среде. К ним относятся основы планетной аэрономии, механика многокомпонентных турбулентных реагирующих газов и гетерогенных многофазных сред, неравновесные кинетические процессы, оригинальные методы математического моделирования атмосфер планет и газовых оболочек комет, миграционно-коллизионные процессы малых тел в космическом пространстве. В своей научной деятельности он прекрасно сочетает теоретические и экспериментальные исследования, принимал непосредственное участие в осуществлении целого ряда наших всемирно признанных космических проектов.

Настоящий биографический очерк отражает взгляд многих коллег Михаила Яковлевича по Институту прикладной математики им. М.В. Келдыша РАН, в котором он проработал около полувека - объективный, но не беспристрастный, а проникнутый восхищением, уважением и любовью.
\end{abstract}

2010 Mathematics Subject Classification: 85 A35, 91B50, 82C40.

Key words and Phrases: Continuum mechanics, non-equilibrium kinetic processes, planetary research and cosmogony. 


\section{1. НАЧАЛО ТВОРЧЕСКОГО ПУТИ}

Судьба распорядилась так, что Михаил Яковлевич Маров (рис. 1.) оказался на отрезке пространства и времени, когда человечеству открылась возможность выйти в космос, начать его изучать и освоение. Ему довелось принимать самое непосредственное участие в этом поистине историческом свершении в великой стране - Советском Союзе - практически с самых первых шагов. Ему посчастливилось заниматься любимой наукой на протяжении долгих лет вместе с многочисленными коллегами и учениками в двух великолепных организациях Российской академии наук, где ему довелось работать, - в Институте прикладной математики им. М. В. Келдыша (ИПМ им. М. В. Келдыша РАН), где он возглавлял отдел прикладной механики, космических исследований и аэрономии, и в Институте геохимии и аналитической химии им. В. И. Вернадского (ГЕОХИ РАН), в котором он возглавляет крупный отдел планетных исследований и космохимии, всемерно способствуя сотрудничеству между ИПМ, Институтом космических исследований (ИКИ) и ГЕОХИ в космических проектах.

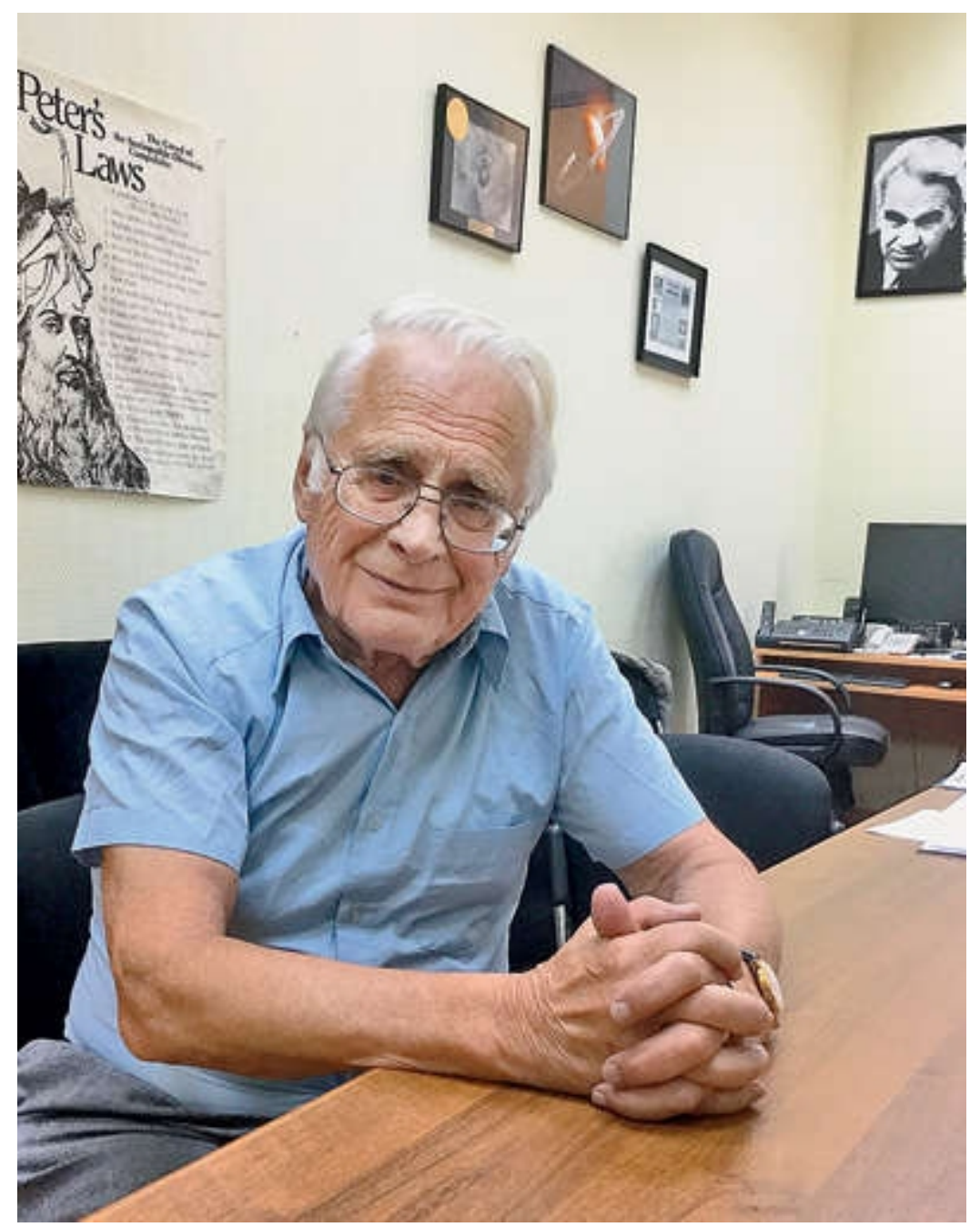

Рис. 1. Академик Российской академии наук Михаил Яковлевич Маров 
Михаил Яковлевич Маров родился в 1933 г. в Москве, в простой семье (рис. 2.). Его отец - участник Великой Отечественной войны, был тяжело ранен, рано умер. Его мать - преподаватель Московского института химического машиностроения. После окончания в 1952 г. московской средней школы с золотой медалью Михаил Яковлевич поступил на механический факультет Московского высшего технического училища (MВТУ) (ныне Московский государственный технический университет) имени Н. Э. Баумана (МГТУ) и окончил его с отличием в 1958 г. Свои школьные и студенческие годы Михаил Яковлевич вспоминает с тёплым чувством, хотя время было тяжёлое, мама, что называется, «поднимала» его одна, заложив духовные, нравственные основы жизни. Он неоднократно говорил, что бесконечно благодарен своим родителям, которые не только подарили ему жизнь, но сделали это крайне своевременно, так что он окончил университет как раз к началу космической эры. На последних курсах университета Михаил Яковлевич изучал сложный раздел механики - нелинейные колебания и был студентом-дипломником, когда пришло известие о запуске в СССР первого в мире искусственного спутника Земли. Оно потрясло его до глубины души. Тогда впервые он задумался о космосе, но мечта хоть как-то к этому приобщиться казалась тогда несбыточной.
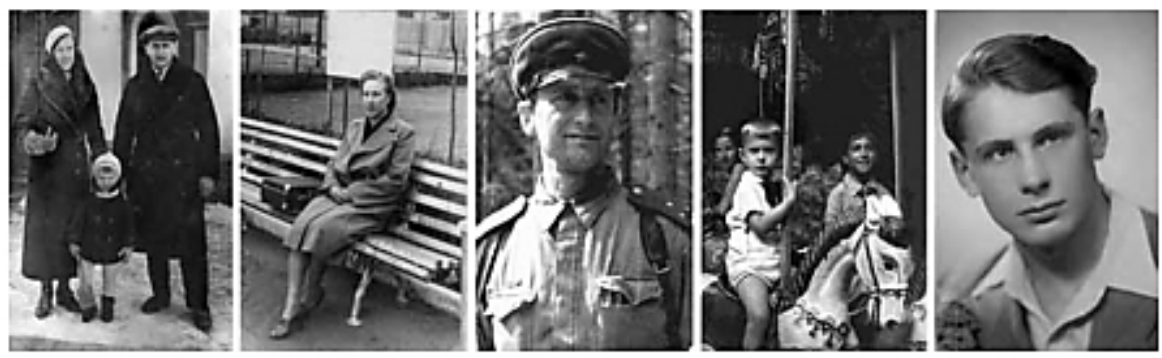

Рис. 2. Родители, детство, юность

Его жизненный путь оказался совсем не простым. После окончания университета Михаил Яковлевич был направлен на закрытое предприятие под Москвой. Он приложил немало усилий, чтобы заниматься там исследовательской, а не рутинной инженерной работой. В течение первых двух лет он занимался нелинейными процессами в атомной физике, много времени проводил в Физико-энергетическом институте имени А. И. Лейпунского в Обнинске, участвуя в экспериментах на атомных реакторах. Как он узнал позже, эти исследования не только предназначались для оборонных проектов, но были связаны также с космосом и предназначались для использования в перспективе в бортовых энергетических установках дальних космических аппаратов (КА) и проводились по распоряжению С.П. Королева. Вскоре, однако, произошла реорганизация - предприятие, в котором Михаил Яковлевич работал, присоединили к ОКБ-1 С. П. Королёва (ныне Ракетно-космическая корпорация имени С.П. Королёва «Энергия» - РКК «Энергия»), а его лаборатория вошла в состав подразделения для разработки систем управления и ориентации космических аппаратов. Это направление возглавлял крупный учёный академик Б. В. Раушенбах, тесное общение с которым продолжалось потом долгие годы. Михаил Яковлевич принимал активное участие в разработке навигационных систем первых космических аппаратов для полётов к Марсу и Венере серий $1 \mathrm{MB}$ и $2 \mathrm{MB}$. Всё тогда было внове, 
многое постигалось буквально на ходу, а несовершенство технических средств часто приводило к досадным ошибкам. И, тем не менее, в кратчайшие сроки создавались совершенно уникальные системы, во многом мотивированные императивами холодной войны, стремлением превзойти соперника, быть первыми.

Вскоре, однако, судьбе было угодно вновь круто изменить жизнь Михаила Яковлевича. Неожиданно распоряжением Госкомитета по оборонной технике (ГКОТ), к которому относилось ОКБ-1, его перевели в Москву, где под непосредственным руководством выдающегося специалиста отрасли Г.А. Тюлина он вплотную занялся текущими и перспективными проблемами ракетно-космической техники, в том числе анализом аварийных пусков ракет.

А после случайной встречи с М. В. Келдышем на одном из совещаний, посвященном проблеме лунной гонки, Михаил Яковлевич получил вскоре его приглашение перейти из системы ГКОТ в Академию наук СССР, в возглавляемый им Институт прикладной математики, которое он принял с воодушевлением. Вся его последующая жизнь на протяжении более полувека связана с Академией наук, где он прошёл колоссальную школу от научного сотрудника до руководителя научного подразделения. Так или иначе, космос определил выбор его жизненного пути. Путь этот оказался достаточно сложным, было несколько крутых поворотов, были, несомненно, моменты везения, но за всем этим стояли упорный труд, непрерывная учёба, не покидавшая его любознательность, стремление к познанию нового.

\section{2. КОСМИЧЕСКИЕ ПРОГРАММЫ И ПРОЕКТЫ}

Особенно серьёзной школой, неизмеримо расширившей научно-технический кругозор и давшей бесценный опыт работы с крупными коллективами и проектами, стала его работа в течение около 15 лет Учёным секретарём Межведомственного научно-технического совета по космическим исследованиям (МНТС по КИ) при АН СССР, который возглавлял М.В. Келдыш.

Все эти годы Михаил Яковлевич работал в тесном общении с ним (рис. 3), и это был самый напряжённый и, вместе с тем, насыщенный период его жизни. Михаил Яковлевич самым непосредственным образом участвовал в разработке программ научных и прикладных космических исследований, обсуждении практически всех

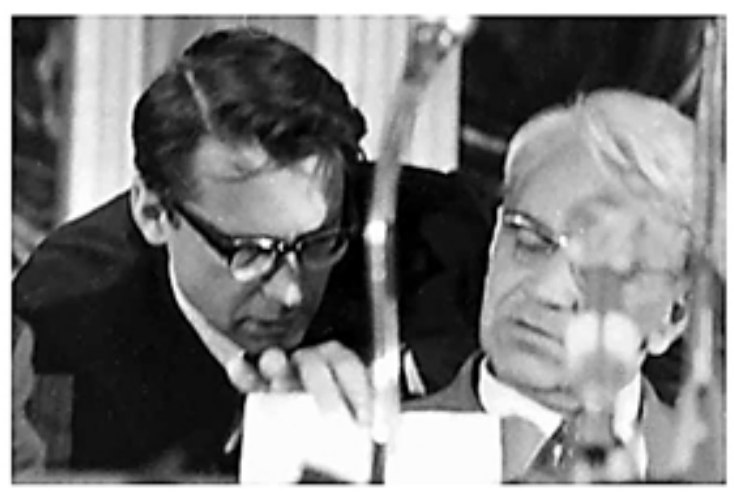

Рис. 3. М.В. Келдыш (справа) и М.Я. Маров, 1971 г. космических проектов, много времени проводил на предприятиях и ракетных полигонах. Ему довелось лично хорошо узнать всех главных конструкторов отрасли, руководителей и ведущих сотрудников НИИ и КБ, в том числе всех членов легендарного Совета Главных конструкторов, возглавляемого С.П. Королевым и самого Сергея Павловича. Это неизмеримо обогатило жизнь.

Среди многих исторических личностей особенно тесные контакты установились у Михаил Яковлевич с Г.Н. 
Бабакиным - Главным конструктором Научно-производственного объединения (НПО) им. С.А. Лавочкина, где создавались космические аппараты для исследований Луны и планет, его заместителями, а затем и преемниками. М.В. Келдыш поручил Михаил Яковлевич лично активно участвовать в выработке программ исследований и подготовке технических вопросов, обеспечивающих решение принципиально важных научных задач, сопряжение научной аппаратуры со служебными системами космических аппаратов для исследований Луны, Венеры, Марса, и он в течение многих лет по существу выполнял функции, которые на Западе называют Project Scientist (PS). Михаил Яковлевич проводил также собственные экспериментальные исследования на этих КА в качестве Principal Investigator (PI), чему М.В. Келдыш всячески способствовал, создав в отделе в ИПМ специальную лабораторию. Кульминационным в этой его деятельности был период с середины 1960-х до начала 1980-х гг. Именно на этот период приходятся выдающиеся пионерские достижения в исследованиях Луны, Венеры, Марса (рис. 4 -7).
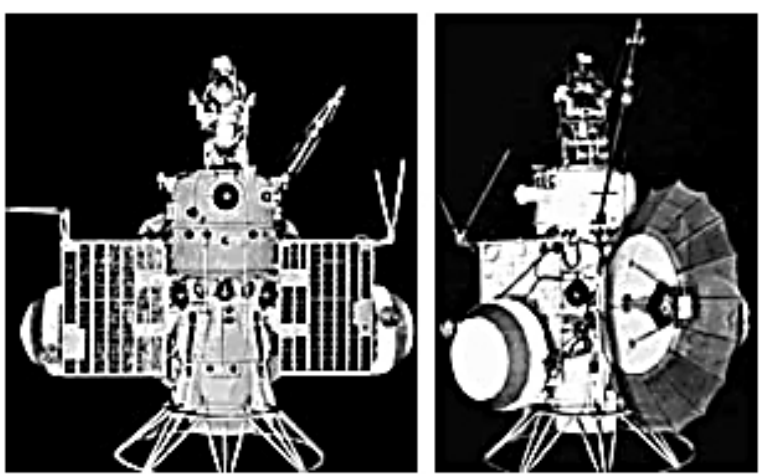

Рис.5. 2МВ - «Венера-2, -3».
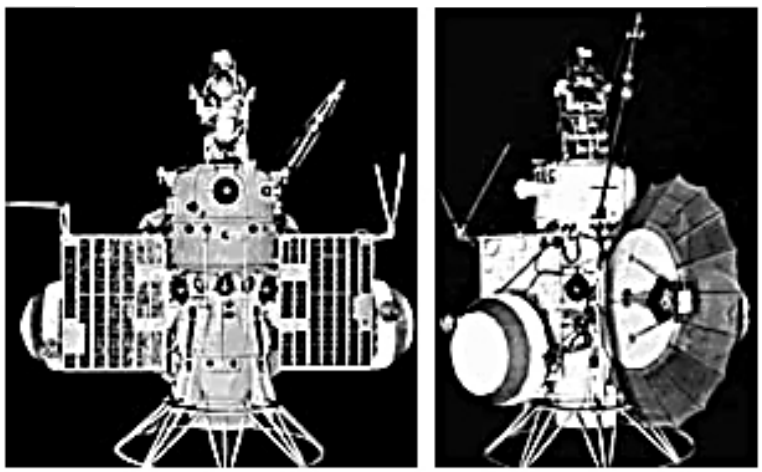

Рис.6. 1МВ - «Марсник».
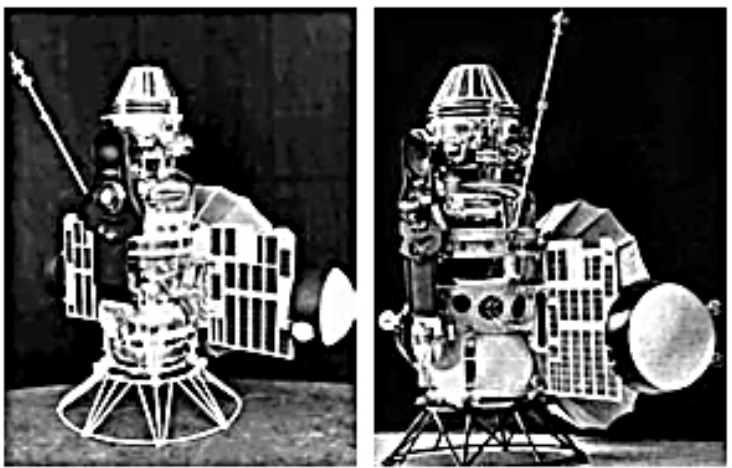

Рис.5. 2МВ - «Венера-2, -3».
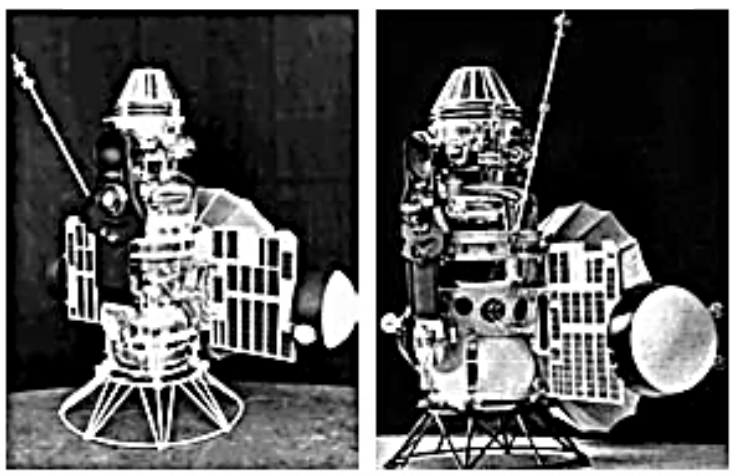

Рис.7. 1МВ - «Венера-1».

С чувством особой гордости Михаил Яковлевич вспоминает об успешной многолетней программе исследований Венеры, начиная с полета «Венеры-4» (рис. 8 10). Осуществлению этой программы он отдал много времени и сил, но эти усилия были с лихвой вознаграждено техническими и научными результатами мирового уровня. Среди них первые прямые измерения параметров атмосферы этой загадочной планеты, первые посадки аппаратов на поверхность Венеры и их выживание в суровых условиях окружающей среды (не повторенные больше никем в мире), измерения освещённости и передача сначала черно-белых, а затем цветных панорам поверхности, 
определение состава поверхностных пород, исследования атмосферной динамики, структуры и свойств венерианских облаков. Российскими учёными были, изучены особенности околопланетного космического пространства на первых искусственных спутниках Венеры. Все эти успехи были достигнуты двумя поколениями космических аппаратов, созданных Г. Н. Бабакиным, причём второе поколение, обладавшее высокой степенью надёжности, стало также технической основой программы полёта аппаратов «Вега» к комете Галлея и создания астрофизического спутника «Астрон».

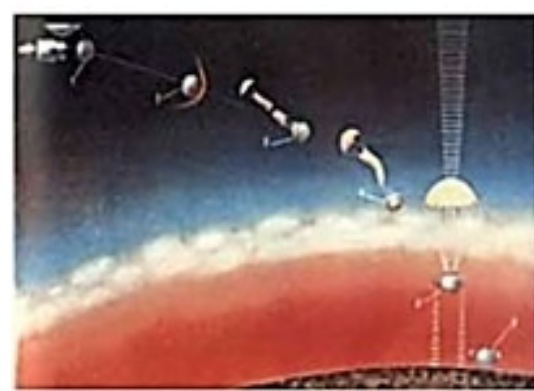

Рис.8. Вход спуск в атмосфере («Венера-4»- «Венера-6»)
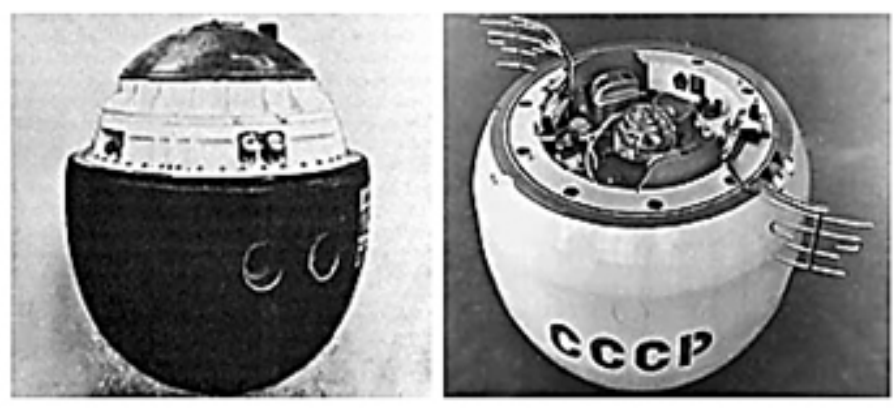

Рис. 10. Спускаемый аппарат, «Венера-7, -8»

К сожалению, не все планы исследований Венеры удалось осуществить. Для Михаила Яковлевича особенно болезненным было решение в 1981 г. об отмене запланированного запуска аэростатного зонда (баллона) для детального изучения уникальных облаков планеты. Сделано это было волевым решением, хотя этот советско-французский проект, научными руководителями которого с российской и французской стороны были, соответственно, М.Я. Маров и Жак Бламон, находился на завершающей стадии изготовления. Этому проекту было отдано около трех лет жизни, потраченными по существу впустую.

Менее успешной была российская марсианская программа, включавшая искусственные спутники Марса и посадочные аппараты. Тем не менее, выдающимися достижениями стали первая мягкая посадка на Марс КА «Марс-3» и первые прямые измерения параметров атмосферы на КА «Марс-6». На этой основе Михаилом Яковлевичем с сотрудниками была создана первая модель атмосферы Марса от поверхности до 70 км.

И, конечно, поистине эпохальными стали уникальные полёты лунных космических аппаратов (рис. 11, 12), обеспечивших автоматический забор и возврат на Землю 
лунного грунта и длительную работу на поверхности Луны самоходных аппаратов. Успешное осуществление этих проектов в самом начале 1970-х гг. позволило в определённой степени ослабить негативные последствия проигранной нами лунной гонки за высадку первого человека на Луну. Михаил Яковлевич неоднократно вспоминает обуревавшие его сложные чувства, когда он наблюдал выход на лунную поверхность Нейла Армстронга - сочетание гордости за триумф человеческого гения вместе с чувством досады и горечи, что это сделали не россияне. Всего лишь восемь лет назад, когда всех захлестнуло ликование от полёта Юрия Гагарина, это казалось вполне реальным. С.П. Королёв готовил даже проект пилотируемого полёта на Марс, всему этому помешала его преждевременная кончина. И, тем не менее, советские лунные автоматы позволили, что называется, сохранить лицо и получить результаты, которыми сегодня по праву гордится страна. Они закрепили за СССР признание его ведущей космической державой.

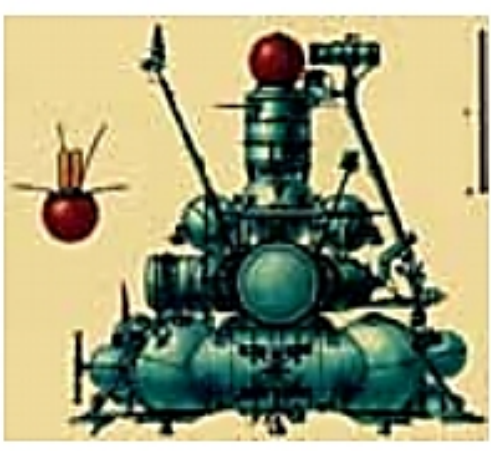

Рис.11. «Луна-16»

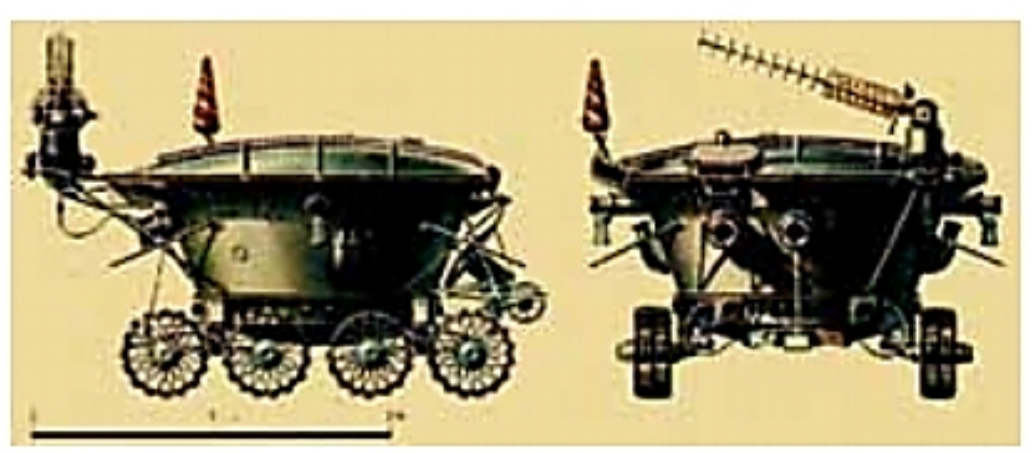

Рис.12. «Луноход-1»
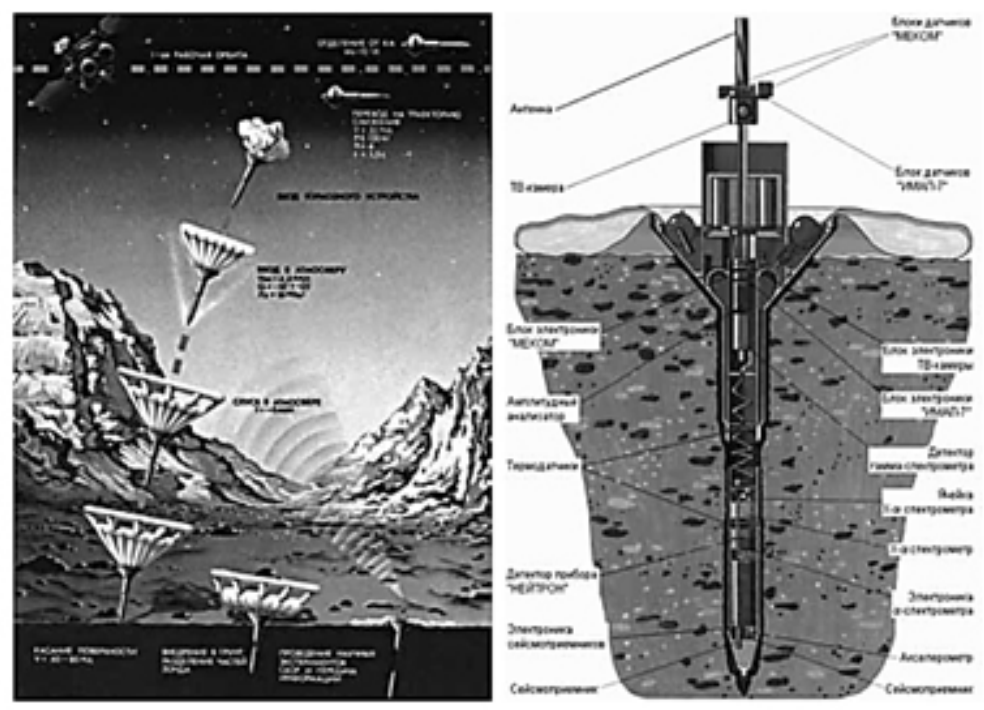

Рис.13. Спуск пенетраторов на поверхность Марса и метеокомплекс «Меком» наверху пенетратора (проект МАРС-96)

Ситуация радикально изменилась, а признание сильно пошатнулось в последующие десятилетия. Успешное завершение миссий ВЕГА было предопределено надёжностью 
КА «Венера» второго поколения. Новые разработки оказались значительно менее совершенными, результатом чего стало выполнение лишь малой части программы полётов двух аппаратов к Фобосу, а вслед за тем и трагедия с запуском КА «Марс-96» (рис. 13). В совокупности с разрушительными последствиями перестройки это отбросило российскую лунно-планетную программу на десятилетия назад. Конечно, огромное негативное влияние оказало отсутствие лидера такого масштаба, как М.В. Келдыш, никто из последующих руководителей космической программы не мог с ним сравниться, не обладал таким колоссальным авторитетом у руководства страны. В конце 1970-х гг., после кончины М. В. Келдыша, Михаил Яковлевич добровольно ушёл из МНТС по КИ и целиком переключился на научную работу, совмещая теоретические и экспериментальные исследования.

В проекте «ВЕГА» Михаил Яковлевич занимался расчётами негравитационных возмущений в движении кометы Галлея вследствие сублимации газа и пыли с поверхности ледяного ядра, с целью повышения точности определения траектории на момент встречи с кометой космического аппарата. В проекте «ФОБОС-88» он занимался моделированием дистанционного определения состава поверхностных пород Фобоса с помощью разработанного в ИКИ РАН бортового прибора «Лима-Д», снабжённого лазерной пушкой и масс-анализатором эжектируемых ионов.

В проекте МАРС-96 он был научным руководителем метеокомплекса, установленного на пенетраторах, отделявшихся от орбитального аппарата и предназначавшегося для длительных измерений параметров атмосферы Марса и вариаций содержания в атмосфере пыли.

Неудача с запуском «Марса-96» оказала катастрофическое влияние на российскую планетную программу. К счастью, в конце 1990-х годов небольшая команда энтузиастов вместе с Михаилом Яковлевичем предприняла героические усилия к ее возрождению. Были учтены многие изменения в стране и, в частности, в космической отрасли, продиктованные новыми экономическими отношениями в рыночных условиях и новые технологии. Постепенно к этой команде присоединились традиционные группы квалифицированных специалистов. Их совместные усилия позволили разработать предложения по созданию универсального планетного космического аппарата. В качестве первой миссии был предложен проект «Фобос-Грунт» для выполнения амбициозной задачи по возвращению на Землю образцов пород со спутника Марса Фобос. Снова Михаил Яковлевич отдал много времени и сил этому проекту, который был, наконец, включен в Федеральную космическую программу. Тем сильнее были переживания в 2011 г. в связи с его неудачным запуском.

Насыщенный крупными событиями почти 20-летний период активной космической деятельности Михаила Яковлевича отражён в его книге «Советские роботы в Солнечной системе. Технологии и открытия» (рис. 14, 15), написанной совместно с американским коллегой Уэсли Теодором Хантрессом и изданной в 2011 г. на английском языке издательством Springer-Praxis, a 2013 г. выпущенной на русском языке редакцией физико-математической литературы издательства «Наука» (М.Я. Маров, У.Т. Хантресс, Советские роботы в Солнечной системе. Технологии и открытия/Пер.: W.T. Huntress, M.Ya. Marov, Soviet robots in the solar systems. Mission technologies and discoveries. М.: Физматлит, 2013. 612 с.). 
В этой книге совершенно объективно отражены успехи и неудачи советской программы лунно-планетных исследований на автоматических КА, проанализированы их причины. На обложку книги, по предложению Уэсли Хантресса, вынесены слова: «Первые на Луне, первые на Венере, первые на Марсе», что отдаёт должное нашему выдающемуся вкладу в мировую науку. Книге была присуждена премия Международной академии астронавтики за лучшую книгу в области фундаментальных наук. Она с интересом встречена российскими читателями, в первую очередь, молодёжью, слабо знакомой с замечательным вкладом отечественной науки и техники в мировую космонавтику.

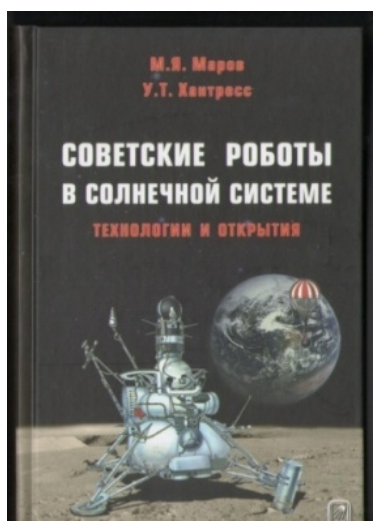

Рис. 14. Издание на русском языке

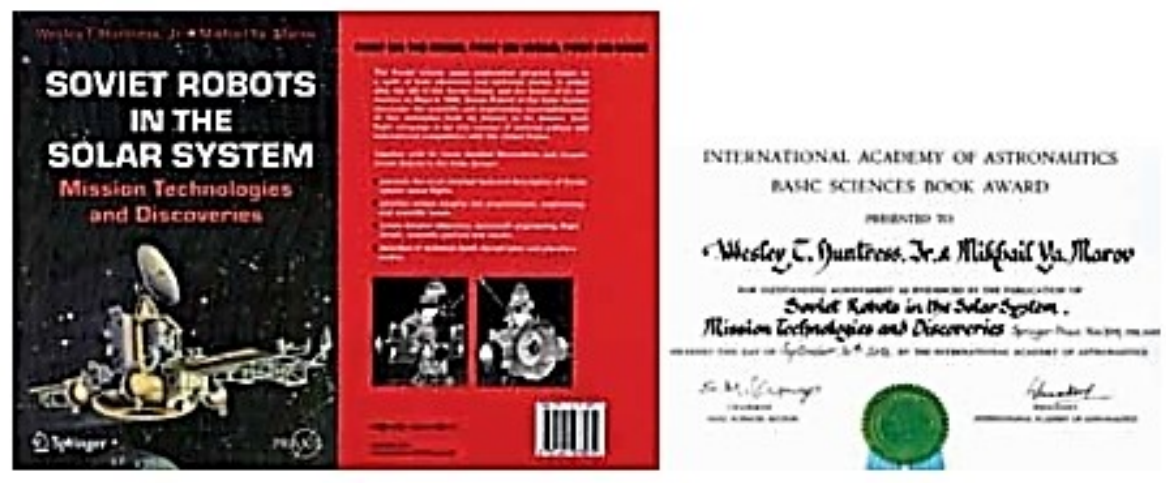

Рис. 15. Книга "Soviet robots in the solar systems. Mission technologies and discoveries", изданная в 2011 г. на английском языке издательством Springer-Praxis, и Диплом Международной академии астронавтики за лучшую книгу в области фундаментальных наук.

Несмотря на завесу секретности, в условиях которой осуществлялась в СССР космическая программа, многое на Западе было известно, в том числе, и об участии Михаила Яковлевича в этой программе. Было, в частности, известно о его позиции у М.В. Келдыша - руководителя советской космической программы. Помимо этого, М.В. Келдыш поручал Михаилу Яковлевичу участие в различных международных мероприятиях, ведение переговоров. Иными словами, Михаил Яковлевич был, что называется, на виду. Неслучайно поэтому в 1971 г., после успешной мягкой посадки на Марс КА «Марс-3», ему была присуждена Международная Галаберовская премия по астронавтике, которую при её вручении Михаил Яковлевич назвал признанием, в первую очередь, заслуг его коллег из НПО им. С.А. Лавочкина. Свидетельством оценки его участия в различных космических проектах у зарубежных учёных стал коллаж Брауновского университета (США), вручённый ему в связи с 20-летием симпозиума «Вернадский -Браун» (рис. 16).

Приятной неожиданностью стало также присуждение Михаил Яковлевич в 2012 г. Диплома НАСА в связи с 50-летием исследований Солнечной системы «в знак признания лидирующей роли в исследованиях Солнечной системы и открытий, изменивших мир» (рис. 17), а в 2013 г. - Премии Элвина Сиффа «в знак признания выдающегося и уникального вклада в планетные исследования, включая первые прямые измерения в атмосферах Венеры и Марса» (рис. 18). 


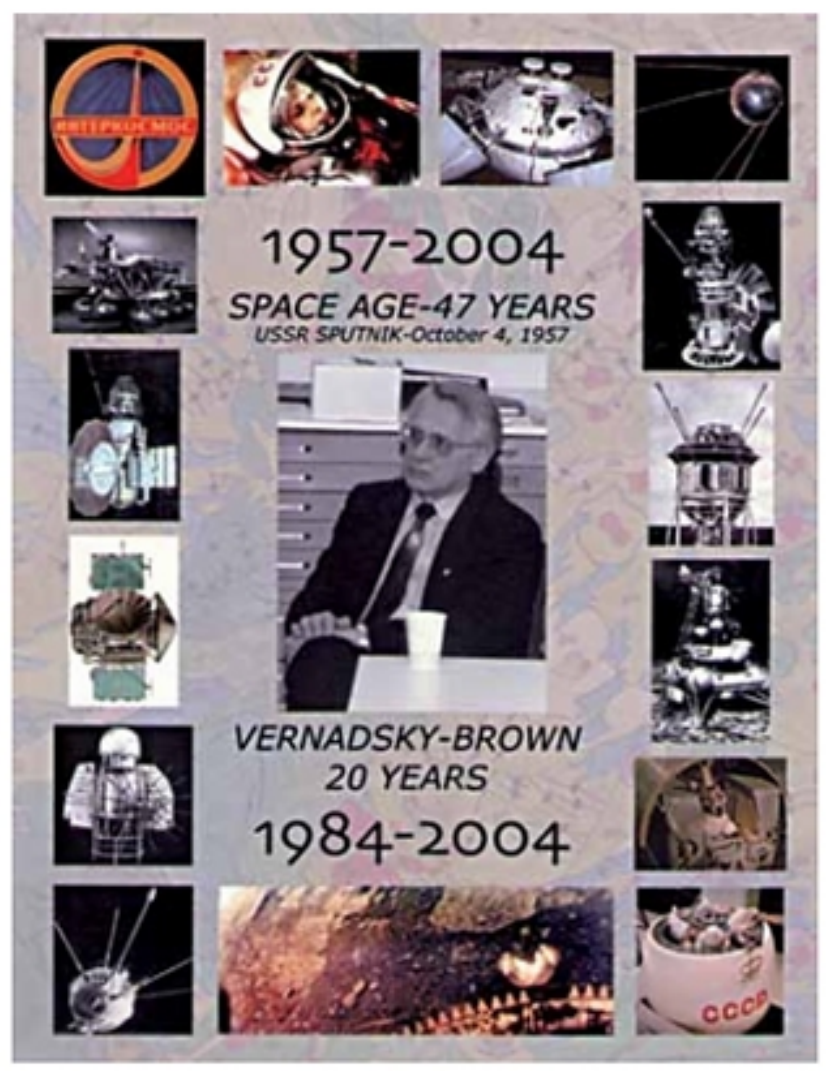

Рис. 16. Коллаж Брауновского университета (США), врученный автору в связи с 20-летием симпозиума «Вернадский - Браун».

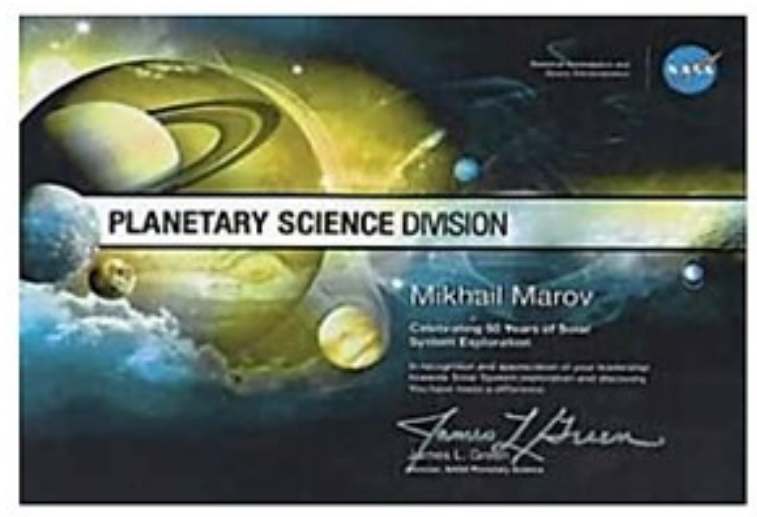

Рис. 17. Диплом НАСА в связи с 50-летием исследований Солнечной системы «в знак признания лидирующей роли в исследованиях Солнечной системы и открытий, изменивших мир».

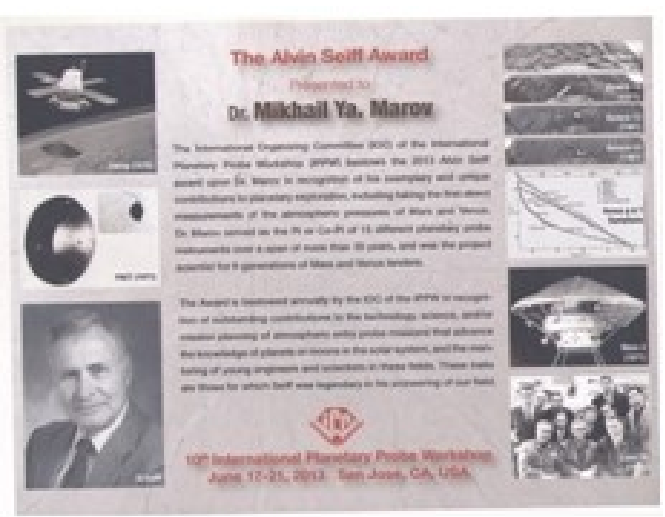

Рис. 18. Премия Элвина Сиффа за планетные исследования.

Книга «Soviet robots in the solar systems. Mission technologies and discoveries», изданная в 2011 г. на английском языке издательством Springer-Praxis была удостоена 
Диплома Международной академии астронавтики за лучшую книгу в области фундаментальных наук. В 2013 г. она была выпущена на русском языке Издательством физико-математической литературы.

\section{3. НАУЧНЫЕ ИССЛЕДОВАНИЯ}

Наряду с работой в МНТС по КИ, Михаил Яковлевич возглавлял в ИПМ отдел прикладной механики, космических исследований и аэрономии, занимаясь теоретическими и экспериментальными работами. Такое совмещение было непростым и требовало колоссальной отдачи сил. Мстислав Всеволодович направлял научную деятельность этого подразделения, помогал в решении ряда теоретических проблем, которые Михаил Яковлевич с ним обсуждал, и эти уроки были бесценными. В 1962 г. Михаил Яковлевич поступил в аспирантуру, в 1964 г. защитил кандидатскую, а в 1970 г. - докторскую диссертацию по разделу физико-математических наук.

В 1977 г. ему присвоили звание профессора, в 1990 г. он был избран членомкорреспондентом АН СССР по Отделению механики и процессов управления, а в 2008 г. - академиком РАН по специальности планетные исследования Секции наук о Земле. В этом избрании нашло отражение признание членами Секции важности изучения Земли как одной из планет Солнечной системы на основе сравнительнопланетологического подхода и того вклада, который Михаилу Яковлевичу удалось внести в этот раздел современной науки.

Научные исследования, в которых лично и с коллегами/учениками ему удалось получить определённые результаты, можно разделить на следующие разделы:

1. Физическая механика, математическое моделирование космических и природных сред, аэрономия (Соавторы: проф., д.ф.-м.н. А.В. Колесниченко, чл.корр. РАН Д.В. Бисикало, д.ф.-м.н. В.И. Шематович, к.ф.-м.н. А.М. Алферов, к.ф.-м.н. О.П. Красицкий).

2. Планетные исследования на космических аппаратах, разработка моделей на основе данных измерений (Соавторы: акад. РАН В.С. Авдуевский, д.т.н. М.К. Рождественский, д.ф.-м.н. В.И. Полежаев, д.ф.-м.н., В.В. Кержанович, к.т.н. Ф.С. Завелевич, Н.Ф. Бородин, к.т.н. Ю.П. Карпейский, к.ф.-м.н. Б.Е. Мошкин, к.ф.м.н. А.П. Экономов, к.т.н. З.П. Черемухина, К.К. Мануйлов, к.т.н. В.П. Осипов).

3. Планетная космогония и космохимия -происхождение и эволюции Солнечной системы и планетных систем у других звёзд (Соавторы: проф. А.В. Колесниченко, д.Х.н. В.А. Дорофеева, к.т.н. А.В. Русол, д.ф.-м.н. С.И. Ипатов, к.ф.-м.н. А.Б. Макалкин, к.ф.-м.н. И.М. Зиглина).

Здесь нет возможности подробно изложить даже наиболее значимые результаты, полученные Михаилом Яковлевичем в каждом из этих разделов или их совокупности, к тому же приведённое деление в известном смысле условно. Поэтому мы ограничимся только очень краткими сведениями, а более подробно с содержанием его исследований можно ознакомиться в многочисленных монографиях, написанных им лично или вместе с коллегами. 


\section{1 Физическая механика, математическое моделирование космических и природных сред, аэрономия}

Специфика космической среды и проблемы, с которыми пришлось столкнуться, предопределили разделы механики, на которых сосредоточились исследования Михаила Яковлевича на протяжении почти полувека. Это многокомпонентная радиационная гидродинамика, турбулентность неоднородных реагирующих сред, динамика разреженного газа, физико-химическая кинетика. Эти разделы составили научный базис работ в новом направлении космических исследований - аэрономии, которой Михаил Яковлевич начал заниматься ещё в аспирантуре под руководством профессора В.И. Красовского. Ему Михаил Яковлевич во многом обязан приобретёнными новыми знаниями по физике верхней атмосферы. В этих исследованиях были использованы экспериментальные данные об эволюции орбит искусственных спутников Земли, торможение которых в верхней атмосфере зависит от её состояния -температуры и плотности. Путём решения обратных задач можно определять значения этих параметров среды и их вариации в зависимости от состояния солнечной и геомагнитной активности. Одновременно, вместе со своим первым учеником и коллегой А.В. Колесниченко, Михаил Яковлевич начал заниматься разработкой теоретических основ аэрономии. Это новое научное направление, представляющее собой исследования динамики разреженного газа, подверженного прямому воздействию солнечного электромагнитного и корпускулярного излучений и сопровождаемого реакциями фотолиза (диссоциацией, ионизацией, возбуждением) и многочисленными прямыми и обратными переходами - химическими реакциями, вместе с процессами тепломассопереноса и диффузии. На основе комплекса этих исследований были созданы модели верхней атмосферы Земли, которые использовались для прогноза времени жизни спутников и орбитальных станций, а также при разработке международных стандартных моделей верхней атмосферы CIRA (COSPAR (Committee on Space Research International Reference Model). Были также созданы модели, на основе которых изучались причины уменьшения содержания озона в озоновом слое Земли с учётом влияния различных малых компонентов, в том числе, в рамках европейского проекта GOMOS (Global Ozone Monitoring by Occultation of Stars), и делались прогнозы его эволюции.

Другим направлением аэрономических исследований стало изучение неравновесных кинетических процессов в разреженном газе верхних атмосфер Земли и других планет. Эти исследования были начаты вместе с другим его талантливым учеником В.И. Шематовичем, который в дальнейшем успешно использовал развитые методы для решения проблем астрохимии. В основу были положены методы стохастического моделирования при решении уравнений больцмановского типа с правыми частями, содержащими интегралы реакций. Метод позволяет с хорошей точностью учесть вклад радиационных и химических источников нагрева и эффективность диссипации атмосферных атомов в космическое пространство. Основой служит построение физиковероятностного аналога кинетического явления в виде случайного процесса и численная реализация уравнения эволюции состояния газа в марковской форме с использованием алгоритмов Монте-Карло. Методы статистического моделирования, в разработке которых принимал также участие Д.В. Бисикало, были успешно применены при изучении степени неравновесности состояния ряда компонентов верхней 
атмосферы Земли с учётом скорости ионизации О2, $\mathrm{N} 2$ и $\mathrm{O}$, спектров кинетической энергии «горячих》 атомов кислорода и азота вследствие фотодиссоциации, их функций распределения на разных высотах и спектров кинетической энергии фотоэлектронов. Данный подход был использован также для оценки темпов потери воды на Марсе вследствие нетепловой диссипации тяжёлых атомов из атмосферы планеты. Помимо этого, роль воды в марсианской атмосфере изучалась на других моделях с учётом вклада фотолиза и химических реакций.

К данному разделу исследований относится также моделирование образования и эволюции внутренней комы кометы, с подробным изучением процессов молекулярного переноса в пористом ядре, сублимации газа и пыли с поверхности ледяного ядра, формирования и радиальных профилей макропараметров кнудсеновского слоя у его поверхности. Им совместно с А.В. Колесниченко были сделаны оценки вклада негравитационных возмущений в движение кометы на разных удалениях от Солнца. Помимо этого, были получены радиальные профили макропараметров разреженного газа в газовой оболочке кометы Галлея и оценено положение наблюдаемого фотометрического ядра, смещённого относительно физического ядра из-за эффектов светорассеяния пылью. Эти результаты использовались в проекте ВЕГА.

В работах М.Я. Марова по механике космических и природных сред особое место занимают исследования по проблемам турбулентности многокомпонентных реагирующих газов. Они проводились на протяжении почти трёх десятилетий и продолжают успешно развиваться в настоящее время совместно с А.В. Колесниченко. Результаты, включающие основополагающие теоретические подходы, соответствующий математический аппарат, методы постановки и решения модельных задач, отражены в многочисленных публикациях и ряде монографий авторов, выпущенных ведущими отечественными и зарубежными издательствами «Наука», «Бином. Лаборатория знаний», «Kluwer Academic Publishers» и «Springer» (см. список литературы [1-16]). Эти исследования в значительной степени ориентированы на проблемы космогонии, эволюции газопылевых аккреционных дисков. Следует подчеркнуть, что в этих работах нашло своё отражение новое направление в исследованиях неоднородных турбулентных сред, когда учитывается наличие химических реакций между газовыми компонентами, а также влияние пыли в случае гетерогенной среды. Существенной новизной отличается также рассмотрение гидродинамической спиральности и эффективности образования пылевых кластеров в турбулентных вихрях.

\section{2 Планетные исследования на космических аппаратах, разработка моделей на основе данных измерений}

Этот большой раздел научных исследований целиком связан с экпериментальными результатами. Наиболее крупные результаты были получены М.Я. Маровым в исследованиях Венеры на космических аппаратах «Венера-4» - «Венера-14» (19671981). Ему довелось вместе с коллегами осуществить первые в мире прямые измерения параметров атмосферы Венеры, измерить значения температуры и давления на ее поверхности, изучить термодинамические свойства атмосферного газа. Были изучены особенности динамики атмосферы, получены профили ветра по высоте путем допплеровских измерений при спуске космических посадочных аппаратов и измерена 
скорость ветра на поверхности посредством чашечных анемометров. Эти исследования подтвердили наличие на Венере атмосферной суперротации. Также впервые в мире были проведены измерения характера уменьшения с высотой солнечного излучения в нескольких диапазонах спектра, получены значения освещённости на поверхности и сделан вывод о преобладании красных лучей, придающих поверхности оранжевый оттенок. Эти измерения позволили передать сначала чёрно-белые, а затем и цветные панорамы поверхности, а также получить первые данные о расположении и структуре облаков. Впервые была определена слоистая структура и микрофизические характеристики основных облаков - наличие трёх слоёв и переходных зон, состоящих из трёх мод частиц микронных размеров с различными показателями преломления. Это позволило сделать вывод о том, что частицы облаков совершенно отличны от водяного льда и образованы веществом другой природы, которой оказалась концентрированная серная кислота. Помимо чёткого определения расположения облачных слоёв на высоте от 49 до 68 км над поверхностью, было также выявлено наличие подоблачной (49 до35 км) и надоблачной (выше 68 км) дымки.

Большое внимание М.Я. Маров уделял разработке моделей, в основе которых лежали, в первую очередь, полученные им собственные данные измерений. Это касалось структуры атмосферы и облаков, теплового режима и атмосферной динамики Венеры. На основе прямых измерений высотных профилей температуры, давления и скорости горизонтального ветра на КА «Марс-6» была создана модель, в хорошем согласии с которой оказались последующие более полные измерения на американских посадочных аппаратах «Викинг». Эти исследования стимулировали в дальнейшем разработку методики, по которой был создан прибор «Термофоб» для измерений термических характеристик поверхности Фобоса на КА «Фобос-Грунт» и приборы «Термо-Л» для аналогичных измерений на поверхности Луны на КА «Луна-Ресурс». Наконец, следует упомянуть о работах по механике невесомости, в которых Михаил Яковлевич участвовал в течение ряда лет вместе со своими коллегами. Эти работы позволили ему достаточно глубоко вникнуть в этот перспективный раздел космических исследований и опубликовать ряд совместных научных работ.

\section{3 Планетная космогония и космохимия -происхождение и эволюции Солнечной системы и планетных систем у других звёзд}

Это направление исследований, на котором сосредоточены интересы Михаила Яковлевича Марова в течение последних двух десятилетий. Эта ветвь астрофизики, известная как планетная космогония, уходит своими корнями в средние века, в основополагающие идеи Канта-Лапласа о происхождении солнечной системы. Однако это направление приобрело большой импульс лишь в последнее время, когда стали доступны наблюдения околозвездных дисков с помощью современных астрономических инструментов, а также благодаря открытию экзопланет и новым возможностям математического моделирования с использованием современных компьютеров. Большой вклад вносит анализ структуры и состава внеземного вещества, позволяющий реконструировать ранние процессы химических реакций, фазовых переходов и др.

Теоретической основой создания моделей служит физическая механика, современным разделом которой является механика космических и природных сред. 
Проблемы и методы моделирования, охватываемые планетной космогонией, включают задачи тепломассопереноса, турбулентности, физической кинетики, и во многом они связаны с аэрономией. В последние десятилетия к ним добавилась космохимия. Ограничениями, накладываемыми на модели, служат исследования структуры, химикоминералогического состава вещества метеоритов, специфики изотопных отношений характерных элементов, составляющие предмет космохимии и позволяющие реконструировать процессы происхождения и эволюции небесных тел и, в совокупности с развиваемыми моделями, - планетной системы в целом. В институте ГЕОХИ им. В.И. Вернадского обеспечивается необходимый синергизм этих двух подходов. Комплекс исследований включает в себя моделирование ранней эволюции газопылевого турбулентного аккреционного диска на основе механики гетерогенных сред, в том числе с учётом магнитогидродинамических (МГД) эффектов. Совместно с коллегами разработаны модели термической и динамической эволюции диска на стадии аккреции вещества из молекулярного облака на протосолнце, получены условия формирования субдиска, его фрагментации на рыхлые газопылевые сгущения вследствие гравитационной и/или гидродинамической неустойчивости и их последующего укрупнения при столкновениях, отвечающие ограничениям на сохранение углового момента.

Значительное внимание Михаил Яковлевич уделял, начиная с 1990-х гг. исследованию миграционных процессов в Солнечной системе. Совместно с С.И. Ипатовым им развита модель миграции ледяных тел и пылевых частиц из внешних областей Солнечной системы (пояса Койпера), их промежуточного захвата на орбиты, пересекающие орбиту Юпитера, и последующего дрейфа на орбиты Главного пояса астероидов и к планетам земной группы. Следствием модели является вывод о том, что на этапе интенсивной бомбардировки кометами и астероидами типа углистых хондритов Земля могла получить за счёт гетерогенной аккреции количество воды, сопоставимое с её содержанием в земных океанах, что могло компенсировать утрату летучих на стадии формирования планет земной группы при высоких температурах вблизи Солнца. Аналогичные объемы воды могли получить Венера и Марс, что подкрепляет гипотезу о существовании у них древних океанов. Это направление исследований напрямую связано также с проблемой происхождения земной биосферы. По разделу космогонии Михаил Яковлевич опубликованы многочисленные статьи и ряд монографий. Среди них монографии с проф. А.В. Колесниченко по проблемам турбулентности и самоорганизации, причём их содержание в значительной степени связано с проблемами планетной космогонии. Опубликованы сборники, посвящённые проблемам хаоса, на фоне которого возникают упорядоченные структуры в космической турбулизованной среде, и проблемам образования и эволюции астрофизических дисков $[4,6,9,11]$.

\section{4. МЕЖДУНАРОДНОЕ СОТРУДНИЧЕСТВО И ПЕДАГОГИЧЕСКАЯ ДЕЯТЕЛЬНОСТЬ.}

В профессиональной деятельности акад. М.Я. Марова, особенно в период работы в МНТС по КИ, существенное место занимали вопросы международного сотрудничества. С начала 1960-х гг. он тесно общался с сотрудниками Комиссии по исследованию и использованию космического пространства (которая была открытым 
органом МНТС по КИ) и её председателем - замечательным человеком А.А. Благонравовым. В 1965 г. М.В. Келдыш привлёк Михаила Яковлевича к работе созданного для международного сотрудничества стран социалистического лагеря Совета «Интеркосмос», к которому вскоре примкнула Франция, и эта его деятельность продолжалась в течение многих лет. С этого же времени начались его зарубежные поездки для участия в различных конференциях и симпозиумах. М.Я. Маров возглавлял ряд комиссий и рабочих групп в таких международных научных организациях как COSPAR, IAF (International Astronautical Federation), IAGA (International Association of Geomagnetism and Aeronomy), IAMAP (International Association of Meteorology and Atmospheric Physics), избирался президентом сначала Рабочей группы 16, а затем Дивизиона III (Планетные исследования) Международного астрономического союза (International Astronomical Union - IAU). Со многими зарубежными коллегами у Михаила Яковлевича сложились дружественные отношения, среди них такие выдающиеся учёные, как Карл Саган (Carl Edward Sagan), Томас Голд (Thomas Gold), Жак Бламон (Jacques Blamont), Гордон Петтенгил (Gordon H. Pettengil), Уильям Ирвайн (William Irvine), Бред Смит (Brad Smith), Тоби Оуэн (Tobias C. Owen), Гарольд Мазурский (Harold Masursky), Джерри Соффен (Gerry Soffen), Майкл Карр (Mikhael Carr), Стив Саундерс (Stiff Saunders), Джим Хэд (James Head), Нэсли Хантресс (Wesley Huntress) и др.

В 1971 г. было подписано первое Соглашение между Академией наук СССР и НАСА США о сотрудничестве в космических исследованиях. Его подписали президент АН СССР М.В. Келдыш и первый заместитель директора НАСА Джордж Дейвид Лоу (George David Low) во время визита американской делегации в Москву. Были созданы четыре совместные Рабочие группы: Космос, Луна и планеты; Космическая метеорология; Космическая связь; Космическая биология и медицина. М.Я. Маров. был назначен сопредседателем Рабочей группы по космосу, Луне и планетам, а с американской стороны им стал помощник Директора HACA Ноэль Хиннерс (Noel Hinners). В частности, в рамках этой Рабочей группы был организован телемост для координации исследований Марса при помощи советского и американского КА, с двух сторон которого были М.Я. Маров и Джерри Соффен. Михаил Яковлевич активно участвовал в международном сотрудничестве по проекту «Фобос-Грунт».

У М.Я. Марова большой опыт педагогической работы, включая чтение лекций и руководство аспирантами. Им подготовлено свыше 20 кандидатов и докторов наук. Свыше 30 лет Михаил Яковлевич сотрудничает с Международным космическим университетом (International Space University - ISU). Он, по существу, находился у его истоков, возглавляя много лет факультет космической физики, избирался в Академический совет и Совет директоров. Начиная с 1989 г., он ежегодно читает курсы лекций в этом университете, который выпускает будущих ведущих специалистов в области освоения космоса на международной, междисциплинарной и межкультурной (3I) основе с использованием метода мозгового штурма. Михаил Яковлевич участвует в работе ISU, включая как постоянный кампус в Страсбурге (Франция), так и программы летних сессий, проходящие по всему миру, и это его деятельность получила высокую оценку. В 1994-1995 годах он преподавал в Университете Северной Каролины (США), работая также над космическими проектами. Он является профессором Московского 
университета им. М.В. Ломоносова и в настоящее время читает лекции на факультете космических исследований.

На протяжении многих лет Михаил Яковлевич успешно совмещает с научной научно-организационную работу. Помимо упомянутой деятельности в МНТС по КИ и многочисленных международных органах, он работал и продолжает работать в различных комиссиях, комитетах и советах. В настоящее время является членом Бюро Совета по космосу Российской академии наук (РАН); председателем Комиссии РАН по научному наследию К.Э. Циолковского; заместителем председателя Научного совета РАН по астробиологии; членом экспертной комиссии по пропаганде научных знаний и присуждению научных премий за лучшие работы по популяризации науки. Он ведет постоянный научный семинар в институте Вернадского. Более 3 лет является главным редактором международного научного журнала «Астрономический вестник. Исследования Солнечной системы» (Solar System Research) издаваемого одновременно на русском и английском языках, а также входил в редколлегии ряда международных научных журналов.

С 2009 года Комитет всемирного наследия ЮНЕСКО (WHC) привлек Михаила Яковлевича к деятельности в области астрономии и космического наследия, направленной на увековечение наиболее признанных ракетно-космических центров и космических объектов. С 2012 года он возглавляет временную Рабочую группу по космическому наследию, призванную увековечить исторические центры по созданию и запуску ракетно-космических систем, как выдающееся культурное наследие и достояние всего человечества. С 2009 года Комитет всемирного наследия ЮНЕСКО (WHC) привлек Михаила Яковлевича к деятельности в области астрономии и космического наследия, направленной на увековечение наиболее признанных ракетнокосмических центров и космических объектов. С 2012 года он возглавляет временную Рабочую группу по космическому наследию, призванную увековечить исторические центры по созданию и запуску ракетно-космических систем, как выдающееся культурное наследие и достояние всего человечества.

Михаил Яковлевич опубликовал около 300 научных работ в реферируемых журналах и 18 монографий, изданных ведущими мировыми отечественными и зарубежными издателями [1-16]. Он также ведет активную просветительскую деятельность, популяризируя науку посредством публикаций и телевизионных программ. Он является автором наиболее признанных популярных книг «Планеты Солнечной системы» (наука РН, 1981 1-й и 1986 2-й выпуски) и «Космос. От Солнечной системы до ядра Вселенной» (PHYSMATLIT, 2016 1-й и 2018 2-й выпуски).

М.Я. Маров был избран действительным членом Международной академии астронавтики, членом Британского Королевского астрономического общества. Имеет несколько отличных государственных и международных наград. Он лауреат наиболее заслуженной Ленинской премии и Государственной премии СССР. Его правительственные награды включают орден Трудового Красного Знамени, Орден Почета, Орден Дружбы и медали. Совсем недавно за выдающиеся достижения в науке он был награжден премией Демидова и золотой медалью Келдыша РАН. Среди его международных наград-престижная премия Галаберта по астронавтике, премия Эдвина Сиффа и медаль КОСПАРА Нордберга. 


\section{5. ВЕЛИКИЙ УЧИТЕЛЬ М.В. КЕЛДЫШ}

В заключение хотелось бы еще раз подчеркнуть, что Михаилу Яковлевичу Марову выпала счастливая судьба быть в самом центре многих исторических событий и непосредственно участвовать в выдающихся космических свершениях в великой стране - Советском Союзе. Он пришел в эту область, когда только началось изучение и освоение космоса. Ему довелось плодотворно работать в замечательной области науки и создать свою научную школу. Ему посчастливилось лично знать многих выдающихся людей, посвятивших себя исследованию космоса и пионерским открытиям за

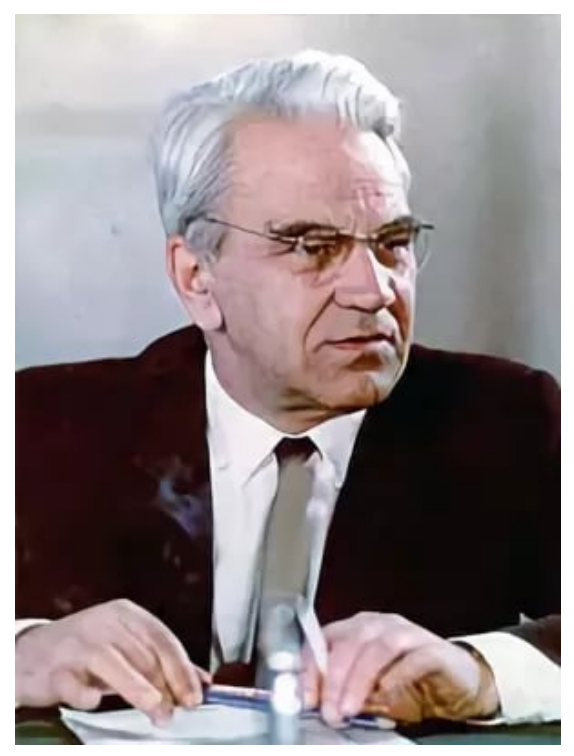

Рис. 19. Великий учитель М.В. Келдыш. пределами собственной планеты. Михаил Яковлевич с теплым чувством вспоминает многих из тех, с кем судьба подарила возможность сотрудничать на коротком отрезке человеческой жизни. Но из всех современников он особо выделяет своего великого учителя Мстислава Всеволодовича Келдыша (рис. 19). О нем он говорит со смесью бесконечного уважения и восхищения. Он усвоил много уроков своего учителя и в науке, и в искусстве управления, но самое главное - воспринял его жизненную философию и мировоззрение. Саму возможность узнать этого выдающегося ученого и удивительного человека, много лет с ним тесно общаться он считает настоящим подарком судьбы.

Приведенная выше биография Михаила Яковлевича Марова - это, по существу, краткий обзор того, что ему удалось совершить, во многом руководствуясь собственным житейским кредо. Ранее, рассказывая об основных направлениях его научной и научно-организационной работы, мы отмечали, что многие результаты этой деятельности и результаты исследований ученого описаны в многочисленных опубликованных книгах и монографиях. Есть, однако, среди этих книг одна, которую Михаил Яковлевич особенно выделяет и ценит. Это - уникальная книга «Космические исследования. М.: Наука. 1981»), основу которой составляет одноименная статья, написанная М.Я. Маровым совместно со своим великим учителем для сборника «Октябрь и наука», выпущенного издательством «Наука» в 1977 году к годовщине Октябрьской революции.

Излишне говорить о том, что Михаил Яковлевич с гордостью вспоминает о приглашении М.В. Келдыша стать его соавтором в этой работе. Дискуссии в процессе подготовки рукописи оставили глубокий след в его памяти.

Коллеги поздравляют Михаила Яковлевича с замечательным юбилеем и желают ему еще многих лет активной жизни и плодотворной деятельности.

\section{REFERENCES}

[1] A.D. Kuz'min, M.Ya. Marov, Fizika planety Venera, M.: Nauka, Gl. red. fiz.-mat. lit., (1974).

[2] M.V. Keldysh, M.Ya. Marov, Kosmicheskiye issledovaniya, M.: Nauka, (1981).

[3] M.Ya. Marov, Planety Solnechnoy sistemy, M.: Nauka, (1986). 
[4] M.Ya. Marov, A.V. Kolesnichenko, Vvedeniye v planetnuyu aeronomiyu, M.: Nauka, (1987).

[5] M.Ya. Marov, V.I. Shematovich, D.V. Bisikalo, Kineticheskoye modelirovaniye razrezhennogo gaza $v$ zadachakh aeronomii, Izd.-vo: M.: IPM im. Keldysha AN SSSR, (1990).

[6] A.V. Kolesnichenko, M.Ya. Marov, Turbulentnost' mnogokomponentnykh sred, M.: MAIK «Nauka», (1998).

[7] M.Ya. Marov, D. Grinspoon, The Planet Venus, Yale University Press, (1998).

[8] M.Ya. Marov, "Malyye tela colnechnoy sistemy i nekotoryye problemy kosmogonii", UFN, 175(6), 668-678 (2005).

[9] M.Ya. Marov, A.V. Kolesnichenko, Mechanics of turbulence of multicomponent gases, Kluwer Academic Publishers, Dordrecht, Boston, London, (2001).

[10] Sovremennyye problemy mekhaniki i fiziki kosmosa. K 70-letiyu so dnya rozhdeniya chl.korr. RAN M.Ya. Marova, (Eds. V.S. Avduyevskogo, A.V. Kolesnichenko), M.: Fizmatlit, (2003).

[11] M.Ya. Marov, A.V. Kolesnichenko, Turbulence and Self-Organization, Modeling Astrophysical Objects, Springer. (2013).

[12] W.T. Huntress, M.Ya. Marov, Soviet Robots in the Solar System. Mission Technologies and Discoveries, Springer -Praxis (2011).

[13] M.Ya. Marov, W.T. Huntress, Sovetskie roboti v Solnechnoy sisteme, Fizmatlit, 2-oe izd., (2018).

[14] M.Ya. Marov, Kosmos. Ot Solnechnoy sistemy vglub' Vselennoy, M.: Fizmatlit, 2-oe izd., (2018).

[15] M.Ya. Marov, I.I. Shevchenko, Ekzoplanety, Institut komp'yuternykh issledovaniy, (2017).

[16] V.I. Shematovich, M.Ya. Marov, "Dissipatsiya planetnykh atmosfer: fizicheskiye protsessy i chislennyye modeli”, UFN, 188(3), 233-265 (2018).

Received May 20, 2019 